\title{
LEGALLY SEPARATED JOINT OWNERSHIP OF BIDDER AND AUCTIONEER: ILLUSTRATED BY THE PARTIAL DEREGULATION OF THE EU ELECTRICITY MARKETS
}

\section{Silvester van Koten}
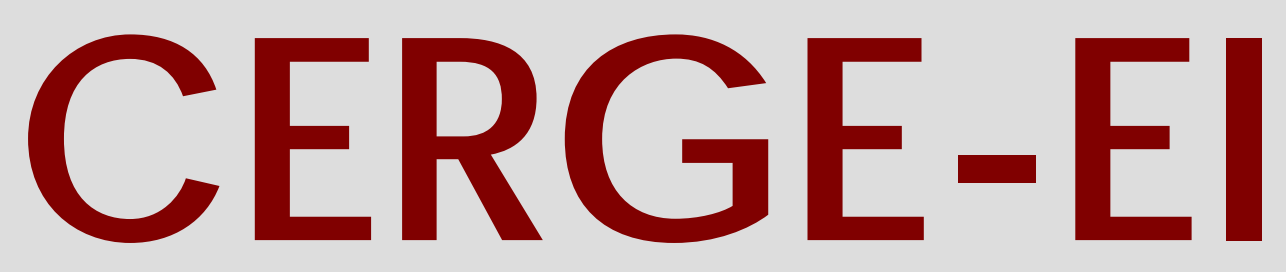

Charles University Centerfor Economic Research and Graduate Education Academy of Sciences of the Czech Republic Ec onomic Institute 


\section{Working Paper Series 346 (ISSN 1211-3298)}

\section{Legally Separated Joint Ownership of Bidder and Auctioneer: Illustrated by the Partial Deregulation of the EU Electricity Markets}

Silvester van Koten

CERGE-EI

Prague, December 2007 
ISBN 978-80-7343-145-7 (Univerzita Karlova. Centrum pro ekonomický výzkum a doktorské studium)

ISBN 978-80-7344-134-0 (Národohospodářský ústav AV ČR, v.v.i.) 


\title{
Legally Separated Joint Ownership of Bidder and Auctioneer: Illustrated by the Partial Deregulation of the EU Electricity Markets ${ }^{\dagger}$
}

\author{
Silvester van Koten* \\ CERGE-EI
}

\begin{abstract}
In the EU electricity industry, many Vertically Integrated Utilities (VIUs) have ownership both of electricity generators and of transmission, hence VIU-owned or allied generators often are bidders in auctions for VIU-owned transmission. In Van Koten (2006) I show that welfare suffers and the holding company benefits - through increased auction revenue - from more aggressive bidding by the allied bidder and that it does not make a difference whether transmission is legally separated from the VIU or not.

Here I analyze the regulatory measure of also legally separating the allied generator from the VIU; this measure effectively transforms the VIU into a holding company and prevents the "VIU" from influencing day-to-day decision-making of the "VIU"-owned generator and bans cross-subsidization between divisions. I show that such a measure may not improve welfare; the holding company can formulate a simple compensation scheme that does not violate the restrictions imposed by legal separation but induces the manager of the allied generator to bid more aggressively, thereby increasing the profits of the holding company and decreasing welfare, as in Van Koten (2006).
\end{abstract}

Keywords: asymmetric auctions, bidding behavior, electricity markets, strategic delegation, regulation, vertical integration.

JEL classification code: L22, L43, L51, L94, L98.

\footnotetext{
$\dagger^{\dagger}$ I would like to thank Libor Dušek, Peter Katuščák, Avner Shaked and Sergey Slobodyan for their excellent comments. Special thanks to Dirk Engelmann and Andreas Ortmann. Financial support from GAČR grant No. 104207 and the REFGOV Integrated project funded by the 6th European Research Framework Programme - CIT3-513420 are gratefully acknowledged. I would also like to thank Laura Strakova for editing the paper.

* Correspondence address: CERGE-EI, P.O. Box 882, Politických vězňů 7, Prague, 111 21, Czech Republic. Tel.: +420776125053; E-mail: Silvester.VanKoten@cerge-ei.cz, SLVSTR@gmail.com.

$\$$ CERGE-EI is a joint workplace of the Center for Economic Research and Graduate Education, Charles University in Prague, and the Economics Institute of Academy of Sciences of the Czech Republic.
} 


\begin{abstract}
Abstrakt
V Evropské unii působí $\mathrm{v}$ oblasti elektroenergetiky mnoho vertikálně integrovaných (sít’ových) firem (VIF), které vlastní jak výrobu elektřiny, tak i přenosová aktiva. Proto se aukcí přenosové kapacity nabízené VIF účastní společnosti prímo vlastněné či jinak spř́izněné s těmito VIF. Ve své dřívější práci, Van Koten (2006), jsem ukázal, že tato struktura vede $\mathrm{k}$ nižší celkové prosperitě a vyšším ziskům holdingové společnosti $\mathrm{z}$ vyšších př́ijmů $\mathrm{z}$ aukce kvůli agresivnějším nabídkám spř́izněného dražitele a že tento výsledek se nezmění, ani když jsou přenosové aktivity právně vyčleněny z VIF.

V této práci zkoumám situaci, kdy je od VIF na základě regulačních předpisů právně oddělen i spř́zněný výrobce elektřiny. Toto opatření fakticky transformuje VIF na holdingovou společnost a zamezuje VIF ovlivňovat každodenní rozhodování výrobce, jehož vlastníkem je VIF, a zakazuj křrižové dotace mezi divizemi. Ukazuji, že toto opatření nemusí vést k vyšší prosperitě. Holdingová společnost může využít jednoduchý mechanizmus odměňování, jenž neporušuje omezení stanovená právním oddělením, který však motivuje vedení spřízněného výrobce elektř̆iny, aby v rámci aukce podával agresivnější cenové nabídky, což vede k nárůstu zisku holdingové společnosti a poklesu prosperity podobně jako ve Van Koten (2006).
\end{abstract}




\section{Introduction}

The present paper is motivated by the current process of liberalization of the electricity market in the European Union (EU). ${ }^{1}$ The two main activities of the electricity industry are generation (the production of electricity) which is done by electricity generators, and transmission (the transport of electricity over long distances) which is done by a Transmission System Operator (TSO). In the past, both generation and transmission were owned by vertically integrated monopolies, also referred to as Vertically Integrated Utilities (VIUs) (European Commission Competition DG, 2007). Even though an active policy of liberalization has been pursued in the EU, VIUs still exist in the form of holding companies that own many of the generation facilities and all, or almost all, of the transmission infrastructure (European Commission Competition DG, 2007).

The combined ownership of transmission and generation by holding companies hampers the liberalization of the electricity industry. Holding companies have incentives to give their own generators (allied generators) preferential access to infrastructure capacity and curb competition by allocating minimal infrastructure capacity to competing new generators. This problem could be especially significant for competition in electricity generation between countries, as transmission lines between countries, called interconnectors, suffer from severe shortages of capacity (European Commission Competition DG, 2007, p.170). ${ }^{2}$

To forestall possible abuse of its dominant position, DIRECTIVE 2003/54/EC and REGULATION 1228/2003 mandate that in case of congestion on a transmission line, the holding company must allocate the access in a non-discriminatory, market-based, and efficient way. This is considered to be done best by implicit or explicit auction

\footnotetext{
${ }^{1}$ This part draws on Van Koten (2006), where a more detailed account can be found.

${ }^{2}$ This is partly a leftover from the past, as the transmission network was not intended to facilitate international power trade (CONSENTEC, 2004). In addition, Léautier (2001) and Brunekreeft, Neuhoff, Newbery (2006) suggest that a holding company might have incentives to underinvest in or even withhold transmission capacity.
} 
(CONSENTEC, 2004). In this paper I will focus on explicit auctions, which are widely used.

However, non-discriminatory access to transmission gives holding companies, in order to lower the competitive pressure on their allied generators, incentives to build less than sufficient transmission capacity. This problem could be especially significant for competition in electricity generation between countries, as transmission lines between countries, called interconnectors, suffer from severe shortages of capacity. In order to alleviate the shortage in transmission capacity, unregulated for-profit building of transmission lines, also referred to as merchant transmission investment, is in principle allowed. This is meant to provide incentives to invest in new transmission capacity. A possible regulatory regime of particular interest suggested by the European Commission $^{3}$ is to allow the transmission owner to keep the profits of a line while still mandating a non-discriminatory, market-based and efficient method of allocating transmission capacity. I will analyze this regulatory regime and refer to it as the Merchant-Non-Discriminatory regulatory regime.

To further counter possible abuse of its dominant position, the European DIRECTIVE 2003/54/EC ${ }^{4}$ and REGULATION $1228 / 2003^{5}$ require, in addition to the above measures, the holding companies to legally separate their transmission activities from their generation activities. I will refer to this requirement as partial legal unbundling. I will refer to legally separating transmission activities and generation activities from one another and from the holding company as complete legal unbundling. Figure 1 illustrates partial and complete legal unbundling of the holding companies.

\footnotetext{
${ }^{3}$ NOTE OF DG ENERGY \& TRANSPORT ON DIRECTIVES 2003/54-55 AND REGULATION 1228103 IN ELECTRICITY; EXEMPTIONS FROM CERTAIN PROVISIONS OF THE THIRD PARTY ACCESS REGIME, 30.1.2004.

${ }^{4}$ Directive 2003/54/EC of 26 June 2003 of the European Parliament and of the Council concerning common rules for the internal market in electricity and repealing Directive 96/92/EC (OJ 2003 L 176/37).

${ }^{5}$ Regulation (EEC) No 1228/2003 of the European Parliament and of the Council on Conditions for Access to the Network for Cross-Border Exchanges in Electricity (OJ 2003 L 176/1).
} 
Figure 1

1a

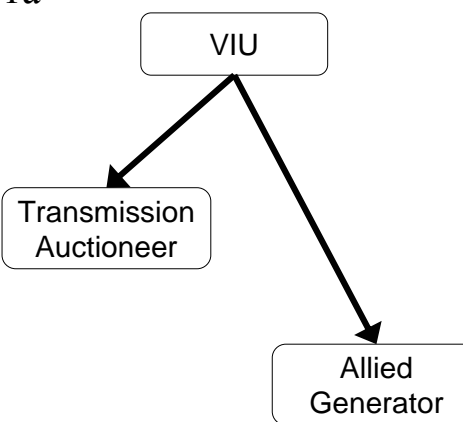

Joint ownership

Legal separation

Full integration of the transmission auctioneer and the allied generator.
$1 b$
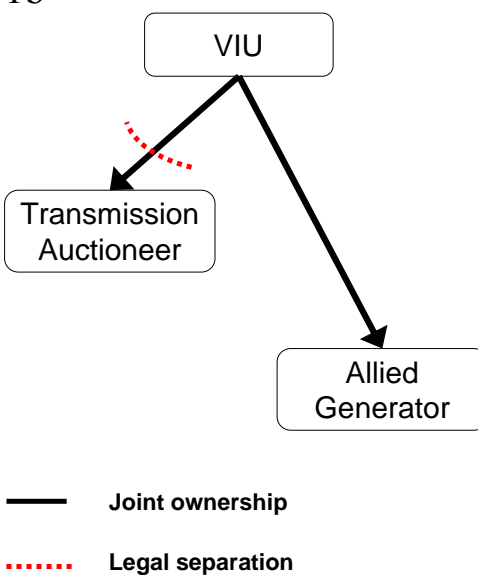

Partial legal unbundling: legal separation of the transmission auctioneer (see Van Koten, 2006).
$1 \mathrm{c}$

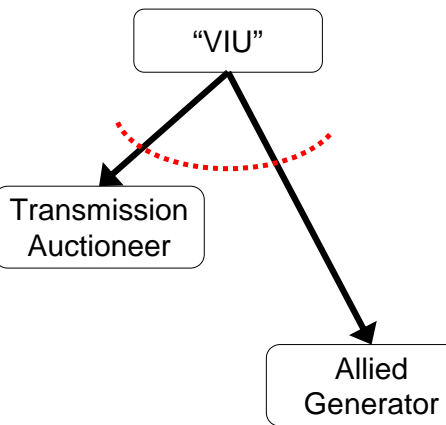

Joint ownership

Complete legal unbundling: legal separation of both the transmission auctioneer and the allied generator (this paper).

Figure 1a gives the initial, fully integrated setup. Figure $1 \mathrm{~b}$ depicts partial legal unbundling as prescribed by DIRECTIVE 2003/54/EC and REGULATION 1228/2003; the holding companies have to move their transmission activities into a legally independent subsidiary. In Van Koten (2006) I have shown this unbundling regime to be insufficient in the Merchant-Non-Discriminatory regulatory regime; when the holding company is partially legally unbundled and the holding company receives the revenues from the auctioning of transmission capacity, then auctions are no longer nondiscriminatory and efficient. The holding company will drive up the price of merchant cross-border transmission lines by aggressive bidding, thus increasing its profits, while decreasing welfare. Figure 1c depicts an alternative regulatory measure, complete legal unbundling, in which the holding companies have to move their transmission activities and their generation activities into legally independent subsidiaries. ${ }^{6}$ Legal separation of the allied generator forces the holding company to delegate decisions to the generator, without being able to influence the day-to-day decision-making. However, the directives allow the holding company to set general performance indicators, compensation

\footnotetext{
${ }^{6}$ While ownership unbundling of the transmission activity, selling the transmission activity to an independent party, would undo the negative effects found in Van Koten (2006), there is strong resistance in the EU to ownership unbundling; many countries have not implemented ownership unbundling and the holding companies in different European countries continue to voice strong protests against unbundling (Van Koten, 2006). In 2005, ownership unbundling of the transmission activity was implemented in only 12 of the then $25 \mathrm{EU}$ member countries (Van Koten and Ortmann, 2006).
} 
schemes and the yearly budget for the bidder. I will show that this allowance de facto might seriously undermine the effect of legal separation of the allied generator.

Specifically, I will analyze the effects of this regulatory measure on the outcomes of transmission auctions. In transmission auctions several generators typically participate as bidders. For simplicity I will consider just two bidders. One of them is the allied generator, who I will refer to as allied bidder $\mathrm{Y}$ and the other one is an independent generator, who I will refer to as independent bidder X.

I will show that the holding company can, by means of a simple compensation scheme, delegate its decision power strategically and increase its profits when participating in transmission auctions. The compensation scheme I consider respects the legal independence of holding company, allied generator and transmission auctioneer; compensation is based on performance indicators of the allied generator only and therefore does not depend on profit indicators of the holding company or the transmission auctioneer. However, the compensation scheme distorts bidding incentives and induces the allied generator to bid more aggressively, thereby increasing the profits of the holding company. I consider one specific functional form, which I call the OwnBid-Kickback scheme ${ }^{7}$ (OBK scheme). This compensation scheme - to offer the manager a linear combination of profit and sales - was originally proposed by Fershtman and Judd (1987) and Sklivas (1987) and is here modified for application in an auctions setting. Use of this compensation scheme also upsets the revenue equivalence between first- and second-price auctions.

The remainder of this paper is organized as follows. In the next section, I analyze the effects of compensation schemes on the outcomes of transmission auctions. I first sketch the general setup, then determine the equilibrium bidding functions of bidders and the equilibrium compensation scheme in second-price auctions, and show the effects on profits and welfare. I then determine the equilibrium bidding functions of

\footnotetext{
${ }^{7}$ It is possible to consider more general forms of compensation schemes, e.g. non-linear ones, but the compensation scheme under consideration is a simple scheme that suffices to show that the holding company can increase its profits this way.
} 
bidders and the equilibrium compensation scheme in first-price auctions and show the effects on profits and welfare. Having obtained these results, I relate my findings to the existing literature. I conclude by discussing the implications of my results for the EU electricity market policy.

\section{Effects of the Own-Bid-Kickback scheme}

\subsection{Setup}

In my model figure two generators that could profitably sell electricity in a distant location. However, the transmission line to this distant location does not have enough capacity for both of them and the right to use the transmission capacity is sold in an auction to the highest bidding generator. Allied generator $Y$, here also referred to as allied bidder $\mathrm{Y}$, is owned by a holding company that also owns a share $\gamma(\gamma: 0 \leq \gamma \leq 1)$ of the transmission capacity. The bidding function of allied bidder $\mathrm{Y}$ is determined by the manager of allied bidder $\mathrm{Y}$, referred to as manager $\mathrm{Y}^{\mathrm{m}}$. Manager $\mathrm{Y}^{\mathrm{m}}$ receives remuneration according to a compensation scheme set by the holding company. The other generator, $\mathrm{X}$, is independent and its manager (" $\mathrm{X}$ ") receives remuneration

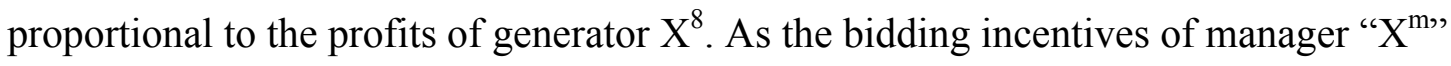
and independent generator $\mathrm{X}$ are identical, I will not distinguish between the two and refer to the independent generator as independent bidder $\mathrm{X}$. The value of transmission is the profit that could be made by selling electricity in the distant location. This profit is equal to the difference between the price in the distant location and the costs of the generator. The generators cannot influence the final price in the distant location, because the transmission capacity is fixed and small relative to the total demand (see e.g. CONSENTEC, 2004).

The value of transmission to a bidder (generator) is drawn from a uniform distribution $v_{i} \in[0,1]$ where $i \in\{X, Y\}$. Values are private and independent. ${ }^{9}$ At the outset, the

\footnotetext{
${ }^{8}$ This is without loss of generality. We will see shortly that the best credible strategy for the independent bidder $\mathrm{X}$ is to induce its manager (" $\mathrm{X}$ ") to maximize profits.

${ }^{9}$ The above assumption is motivated by the fact that there exist price differences between countries that can be profitably exploited. For ease of exposure, the price in the distant location is set equal to one. The size of the profit then depends on the costs of generating electricity. As a generator does not know the
} 
bidders are therefore symmetrical. I assume that the auctioneer auctions off the transmission capacity as one indivisible good. ${ }^{10}$

In line with the literature, I assume that there exists a differentiable, strictly increasing bidding strategy $b_{Y}[\cdot]\left(b_{X}[\cdot]\right)$, that maps the allied bidder's realized value $v_{Y} \in[0,1]$ $\left(v_{X} \in[0,1]\right)$ into his bid $b_{Y}\left[v_{Y}\right]\left(b_{X}[\cdot]\right) .{ }^{11}$ Then the bidding strategy $b_{Y}[\cdot]$ has an inverse $y[\cdot]$ such that $y\left[b_{Y}[v]\right]=v$. Analogously, the optimal bid of the independent bidder X, $b_{X}$, is determined by her bidding strategy $b_{X}[\cdot]$ that maps her realized value $v_{X} \in[0,1]$ into her bid $b_{X}\left[v_{X}\right]$. The strategy $b_{X}[\cdot]$ has an inverse $x[\cdot]$, such that $x\left[b_{X}[v]\right]=v$.

The holding company strives for the highest attainable profit from allied generator $\mathrm{Y}$ and the transmission auctioneer together. Because of legal separation, the holding company cannot influence the day-to-day decision-making of the bidder or the auctioneer. The holding company therefore offers the manager of allied bidder $\mathrm{Y}, \mathrm{Y}^{\mathrm{m}}$, a compensation scheme that serves the interests of the holding company, while respecting the legal independence of the holding company, the allied bidder and the auctioneer. ${ }^{12}$

The holding company can choose to give the manager compensation equal to a proportion $i$ of a linear combination of profits and revenue as considered by Fershtman and Judd (1987) and Sklivas (1987). ${ }^{13}$ Sklivas (1987) shows that such a compensation is

\footnotetext{
cost of his competitors (see e.g. Parisio and Bosco, 2003 and Léautier, 2001), he treats it as a random variable. The costs, $C_{X}, C_{Y} \in[0,1]$, are private and independent.

${ }^{10}$ While transmission capacity is usually auctioned in many units of $1 \mathrm{GW}$, I restrict my focus to singleunit auctions. Excluding multi-unit auctions simplifies the analysis of OBK-schemes in auctions. Multiunit auctions mostly do not have efficient outcomes and mostly cannot be analytically solved, which complicates the task of demonstrating the effects of OBK schemes.

${ }^{11}$ The strategies $b_{Y}[\cdot]$ and $b_{X}[\cdot]$ (and their respective inverses $x[\cdot]$ and $y[\cdot]$ ) are dependent on the ownership share $\gamma$. For notational convenience I will not include the variable " $\gamma$ " in the derivation to follow. I allow for a bidding function $b[\cdot]$ to be strictly increasing on an interval $[0, \bar{v}]$ with $\bar{v}: 0<\bar{v}<1$ and then to be flat on $[\bar{v}, 1]$. In this case the inverse is only defined on $[0, \bar{v}]$.

${ }^{12}$ For a compensation scheme not to violate the legal independence of holding company, allied bidder, and auctioneer, the compensation for the allied bidder ought to be based on performance indicators of the allied bidder only, and not on profit indicators of the holding company or the auctioneer.

${ }^{13}$ Fershtman and Judd (1987) and Sklivas (1987) considered the effect of such compensation schemes in the context of two competing firms who each have a manager that makes the crucial output and pricing
} 
equal to a proportion of the revenues minus costs, where the costs are weighted by factor $a$.

$w=i \cdot(a \pi+(1-a) R)$,

(where $\pi$ is the profit, $R$ is the revenue, and $a$ is the linear weight),

$$
\begin{aligned}
& =i \cdot(a(R-c)+(1-a) R), \\
& =i \cdot(R-a c) .
\end{aligned}
$$

From here on, I will refer to factor $a$ as the cost weight. From this perspective, normal profit maximization is the special case where the cost weight is set equal to unity: $a=1$. Proportion $i$ is determined endogenously in the model, as the expected compensation for manager $\mathrm{Y}^{\mathrm{m}}$ must equal his reservation wage, $w^{0}$ :

$$
\mathrm{E}[w]=\mathrm{E}[i \cdot(R-a c)]=w^{0} .
$$

How does such a scheme affect the bidding behavior of a manager who takes part in an auction? In an auction, the costs and returns are expected values that are endogenously determined by the bids $b$ that the bidders submit. In this case, the expected compensation for the manager is:

$$
\mathrm{E}[w]=i \cdot x\left[b_{Y}\right]\left(v_{Y}-a b_{Y}\right) .
$$

The expected value of the transmission, $x\left[b_{Y}\right] v_{Y}$, corresponds to the revenue. ${ }^{14}$ The expected bid payment of the auction, $x\left[b_{Y}\right] a b_{Y}$, is the expected cost of realizing the "revenue". I will call this the Own-Bid-Kickback (OBK) compensation scheme, as manager $\mathrm{Y}^{\mathrm{m}}$ does not take the full bidding costs into account when $a<1$. In that case, manager $\mathrm{Y}^{\mathrm{m}}$ receives a kickback of $1-a$ times his bid if he wins.

decisions. They found that due to an interactive effect the optimal compensation scheme has a cost weight $a$ such that $a>1(a<1)$ for Bertrand competition (Cournot competition); the optimal compensation scheme exaggerates (understates) a part of the costs and makes the firms competing weaker (stronger). The firms become "fat cats" ("top dogs") in the sense of Fudenberg and Tirole (1984).

${ }^{14}$ We will see shortly that $x\left[b_{Y}\right]$ is the probability of winning the auction. 
In this setup the owner of the allied bidder $\mathrm{Y}$, the holding company, offers manager $\mathrm{Y}^{\mathrm{m}}$ a specific compensation scheme, while the owner of independent bidder $\mathrm{X}$ does not offer its manager (" $\mathrm{X}$ ") ) such a scheme. We will see shortly that the owner of allied bidder $\mathrm{Y}$, the holding company, has incentives to implement a compensation scheme with $a<1$ in both first- and second-price auctions because of its position of residual claimant of the auction. The owner of independent bidder $\mathrm{X}$ does not have comparable incentives in second-price auctions. In first-price auctions, it might seem that the owner of independent bidder $\mathrm{X}$ has incentives to implement a compensation scheme with $a>1$ for strategic reasons, but I will argue that the actual implementation of any compensation scheme with $a \neq 1$ cannot be part of a Nash equilibrium.

\subsection{The second-price auction}

It is a well-known result that in second-price auctions, bidders have a weakly dominant strategy to set their bids equal to their values, regardless of the bidding functions of other bidders. Therefore, independent bidder X has a weakly dominant strategy to bid her own value, regardless of the type of compensation scheme manager $\mathrm{Y}^{\mathrm{m}}$ is offered. As manager Y pays only the proportion $a$ of his bid, it is a weakly dominant strategy for him to set $a$ times his bid equal to his value: $a b_{Y}=v_{Y}$.

The bidding functions for $\mathrm{X}$ and $\mathrm{Y}$ are therefore

$$
b_{X}\left[v_{X}\right]=v_{X}
$$$$
b_{Y}\left[v_{Y}\right]=\frac{v_{Y}}{a} \quad \text { if } v_{Y}<a
$$$$
b_{Y}\left[v_{Y}\right]=1 \quad \text { if } v_{Y} \geq a \text {. }
$$

Figure 2 illustrates the bidding functions of $\mathrm{Y}$ and $\mathrm{X}$ for $a=\frac{1}{2}$. The lower dashed curve is the bidding curve of the independent bidder $\mathrm{X}$ who bids her true valuation. Allied bidder $\mathrm{Y}$ overbids his value, and has a higher probability of winning than before. 
Figure 2

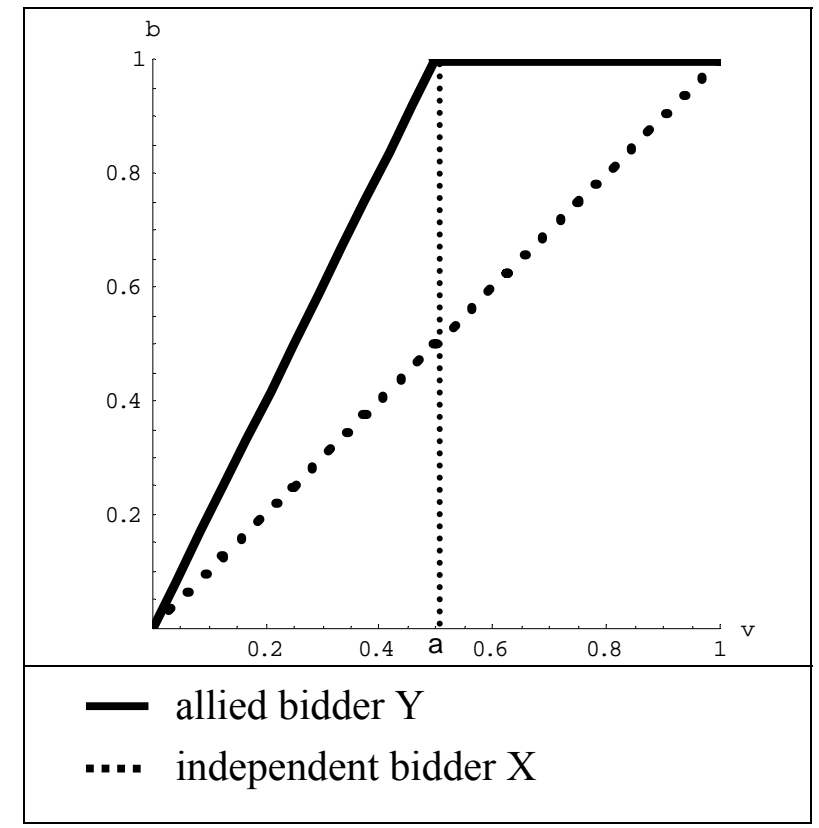

Setting the cost weight $a$ smaller than one induces manager $\mathrm{Y}^{\mathrm{m}}$ to set a more aggressive bidding strategy for allied bidder Y. This bidding strategy has several noteworthy effects on the ex-ante expected auction outcomes. ${ }^{15}$

a. Allied bidder $\mathrm{Y}$ is more likely to win the auction than before, because manager $\mathrm{Y}^{\mathrm{m}}$ now sets more aggressive bids than $\mathrm{X}$.

b. Allied bidder $\mathrm{Y}$ earns lower profits than before, because manager $\mathrm{Y}^{\mathrm{m}}$ now disregards part of the bidding costs and therefore does not maximize profits.

c. The compensation of manager $\mathrm{Y}^{\mathrm{m}}$ is higher than before, because when the cost weight is lower, $\mathrm{Y}^{\mathrm{m}}$ pays a smaller part of the bidding cost.

d. The revenue of the auctioneer (or revenue from the auction), $m[a]=\frac{3-a}{6}$, is higher than before. When $\mathrm{Y}$ loses, the losing bid of $\mathrm{Y}$ is higher, and hence $\mathrm{X}$ pays more for transmission. When $\mathrm{Y}$ wins, $\mathrm{Y}$ either pays the same ( $\mathrm{Y}$ would have won with or without the compensation scheme) or Y pays more (Y would have lost without the compensation scheme).

e. The profit of the holding company (i.e., the profit of both the auctioneer and the allied bidder), $\pi_{\text {Holding Company }}^{Y}[a]=\frac{3+a(1-a)}{6}-w^{0}$, reaches an optimum at $a^{\mathrm{II}} *=\frac{1}{2}$

\footnotetext{
${ }^{15}$ Detailed proofs can be found in proposition 1 in the Appendix.
} 
of $\pi_{\text {Holding Company }}^{Y}\left[a^{\mathrm{II} *}\right]=\frac{13}{24}-w^{0} \approx 0,5417-w^{0}$. Decreasing the cost weight $a$ has two opposing effects on the profit of the holding company. Both effects are the result of the holding company owning a part of the transmission auctioneer; I therefore refer to these effects as the "ownership effects". The first ownership effect is that the aggressive bidding of $\mathrm{Y}^{\mathrm{m}}$ drives up the expected auction revenue, thereby increasing the profit of the holding company. The second ownership effect is that $Y$ is more likely to win when the payment of $\mathrm{X}$ would have been larger than the value of transmission for $\mathrm{Y}$, thereby decreasing the profit of the holding company.

f. Independent bidder $\mathrm{X}$ earns lesser profits than before, $\pi^{X}[a]=\frac{a}{6}$, because $\mathrm{X}$ is less likely to win the auction and when $\mathrm{X}$ wins, she pays a higher price.

g. The strategic profit ${ }^{16}$ of the holding company, $\pi_{\text {Strategic }}^{Y}[a]=\frac{a(1-a)}{6}$ is positive and reaches an optimum at $a^{\mathrm{II} *}=\frac{1}{2}$ of $\pi_{\text {Strategic }}^{Y}\left[a^{\mathrm{II} *}\right]=\frac{1}{24} \approx 0.0417$.

h. Welfare, $W[a]=\frac{(3-a)(1+a)}{6}$, is lower than before because the auction has become less efficient. While $\mathrm{Y}$ has the same value distribution as $\mathrm{X}$, $\mathrm{Y}$ now wins in some cases when he does not have the highest value for transmission. When the holding company chooses the optimum cost weight $a^{\mathrm{II} *}=\frac{1}{2}$, total welfare is $W\left[a^{\mathrm{II} *}\right]=\frac{15}{24}=0.625$, which is $\frac{1}{24}$ lower than maximum welfare.

\section{Partial ownership}

In the more general case the holding company does not fully own the auctioneer, but a share $\gamma \in[0,1]$. The profit of the holding company is then

$$
\begin{aligned}
\pi_{\text {Holding Company }}^{Y}[a, \gamma] & =\pi_{\text {Generator }}^{Y}[a]+\gamma m[a] \\
& =\frac{a(2-a)}{6}+\gamma \frac{3-a}{6} .
\end{aligned}
$$

\footnotetext{
${ }^{16}$ The strategic profit is the extra profit the holding company earns by using a compensation scheme. It is the marginal addition to the profit that results from manager $\mathrm{Y}^{\mathrm{m}}$ changing his bidding schedule. The holding company can maximize the strategic profit by setting the appropriate compensation scheme for manager $\mathrm{Y}^{\mathrm{m}}$.
} 
Maximizing this expression with respect to $a$ gives the optimal cost weight as a function of the ownership share $\gamma$

$$
a^{\mathrm{II}}[\gamma]=\operatorname{ArgMax}_{\alpha}\left[\frac{a(2-a)}{6}+\gamma \frac{3-a}{6}\right]=1-\frac{\gamma}{2} .
$$

Note that $a^{\mathrm{II}}[0]=1$; a holding company that has no ownership share in transmission prefers its bidder to maximize profits in second-price auctions. The effect on bidding of allied bidder $\mathrm{Y}$ is purely driven by the share of ownership: the ownership effect. This result explains why the owner of independent bidder $\mathrm{X}$ has no incentive to offer its manager " $\mathrm{X}$ ") a similar compensation scheme; he has no ownership share in transmission.

Figure 3

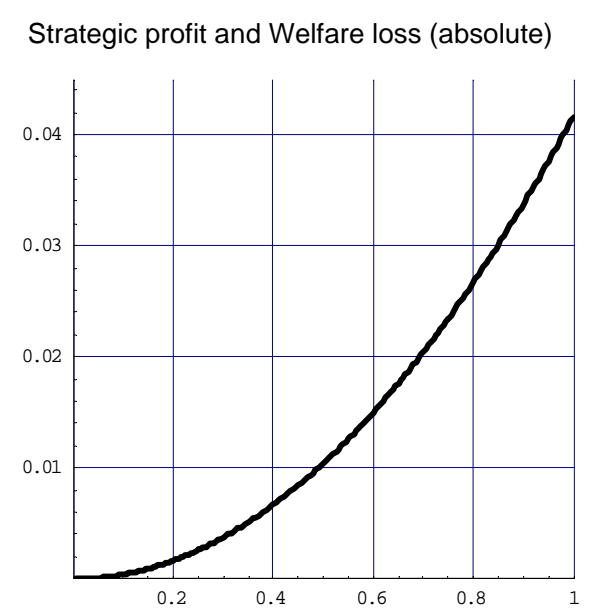

Ownership share $\gamma$

- Welfare loss $W\left[a^{\mathrm{II}}[\gamma]\right]$

- - Strategic profit $\pi_{\text {Strategic }}^{Y}\left[a^{\mathrm{II}}[\gamma], \gamma\right]$

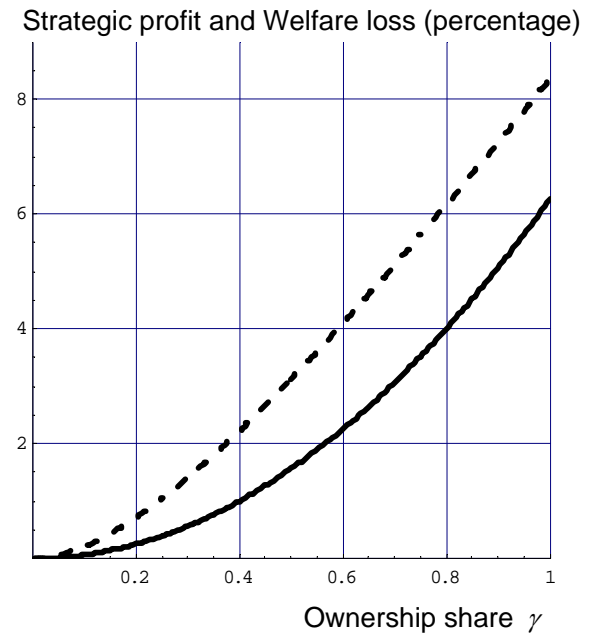

- Welfare loss $W\left[a^{\mathrm{II}}[\gamma]\right]$

- - Strategic profit $\pi_{\text {Strategic }}^{Y}\left[a^{\mathrm{II}}[\gamma], \gamma\right]$

Figure 3 illustrates the strategic profit, ${ }^{17} \pi_{\text {strategic }}^{Y}\left[a^{\mathrm{II}}[\gamma]\right]=\frac{\gamma^{2}}{24}$, and the welfare loss, $W\left[a^{\mathrm{II}}[\gamma]\right]-\frac{2}{3}=\frac{\gamma^{2}}{24}$, for all possible ownership shares $\gamma$ between zero and one ${ }^{18}$. The strategic profit and the welfare loss are strictly increasing in $\gamma$.

\footnotetext{
${ }^{17}$ The ownership share $\gamma$ has a direct and a strategic effect on the profit of the holding company. The direct effect translates into what I will refer to as the "passive" profit and is due to the fact that the holding company receives proportion $\gamma$ of the auction revenue. The "passive" profit is the profit that the
} 


\subsection{The first-price auction}

While in second-price auctions the implementation of a compensation scheme for manager $\mathrm{Y}^{\mathrm{m}}$ does not affect the bidding of manager $\mathrm{X}$, this is not so in first-price auctions. Bidding schedule $\mathrm{X}$ depends on the compensation scheme for manager $\mathrm{Y}^{\mathrm{m}}$, a fact the holding company can use to strategically influence the bidding schedule of X.

Figure 4 depicts the timeline of events in the auction. At time 1, the holding company implements a compensation scheme for manager $\mathrm{Y}^{\mathrm{m}}$ with cost weight $a$. I make two assumptions. Firstly, that $\mathrm{X}$ is perfectly informed about the value of the cost weight. Secondly, that the rules on legal separation forbid the holding company from spreading false information about the compensation scheme. As a result the holding company can be sure that the compensation scheme it announces is known and believed by independent bidder X; this gives the holding company a first mover's advantage. Below, I will relax these two assumptions. At time 2, manager $\mathrm{Y}^{\mathrm{m}}$ and $\mathrm{X}$, anticipating each other's reactions, simultaneously determine the bidding functions $b_{Y}\left[v_{Y}\right]$ and $b_{X}\left[v_{X}\right]$, respectively. At time 3, plugging in their respective values, $\mathrm{Y}$ and $\mathrm{X}$ determine their bids in the auction and the highest bidder wins.

Figure 4

The holding company implements a compensation scheme with cost weight $a$

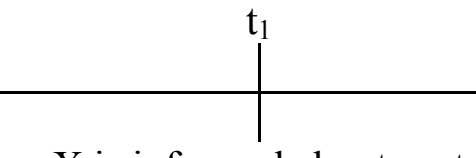

$\mathrm{X}$ is informed about cost weight $a$ (or deduces it)
Bidding functions are determined

Bids are determined and the auction takes place
$\mid \stackrel{t_{2}}{t^{2}} \stackrel{t_{3}}{\mid}$
Manager $\mathrm{Y}^{\mathrm{m}}$ and $\mathrm{X} \quad \mathrm{Y}$ and $\mathrm{X}$ reveal their private simultaneously determine values for transmission $\left(v_{Y}\right.$ the bidding functions $b_{Y}\left[v_{Y}\right]$ and $v_{X}$ ) and determine their and $b_{X}\left[v_{X}\right]$ respectively bids. The highest bid wins the auction 
Given the bidding strategy of $\mathrm{X}, b_{X}\left[v_{X}\right]$, Y wins the auction when bid $b_{Y}$ is larger than the bid of the independent bidder, $b_{X}\left[v_{X}\right]$ :

$$
\begin{aligned}
& b_{X}\left[v_{X}\right]<b_{Y} \Leftrightarrow \\
& v_{X}<b_{X}^{-1}\left[b_{Y}\right] \equiv x\left[b_{Y}\right] .
\end{aligned}
$$

The probability of $Y$ winning the auction is therefore $F\left[x\left[b_{Y}\right]\right]$, which is equal to $x\left[b_{Y}\right]$ as the values are drawn from the uniform distribution on $[0,1]$. The expected profit of allied bidder $Y$ with value realization $v_{Y}$, bidding $b_{Y}$, is therefore

1) $\quad \pi_{\text {Generator }}^{Y}=x\left[b_{Y}\right]\left(v_{Y}-b_{Y}\right)-w^{0}$.

Likewise, the expected profit of independent bidder $\mathrm{X}$ with value realization $v_{X}$, bidding $b_{X}$, is

2) $\quad \pi_{\text {Generator }}^{X}=y\left[b_{X}\right]\left(v_{X}-b_{X}\right)$.

When the compensation scheme of manager $\mathrm{Y}^{\mathrm{m}}$ sets cost weight $a$, then the expected compensation for manager $\mathrm{Y}^{\mathrm{m}}$ is

3) $\pi_{\text {Manager }}^{Y}=i \cdot x\left[b_{Y}\right]\left(v_{Y}-a b_{Y}\right)$.

Without a compensation scheme, $\mathrm{X}$ and $\mathrm{Y}^{\mathrm{m}}$ maximize the profits given by equations 1 and 2 respectively, with a symmetrical outcome for the bidding function $b[v]=\frac{1}{v} \int_{0}^{z} z d z=\frac{1}{2} v$ (e.g. Krishna, 2002). ${ }^{19}$ Offering manager $\mathrm{Y}^{\mathrm{m}}$ a compensation scheme with cost weight $a$ makes him maximize equation 3 . To calculate the reaction function of manager $\mathrm{Y}^{\mathrm{m}}$, differentiate equation 3 with respect to $b_{Y}$, set it equal to zero and solve for $x^{\prime}[b]$ :

4) $\quad x^{\prime}[b]=\frac{a \cdot x[b]}{v_{Y}-a b}=\frac{a \cdot x[b]}{y[b]-a b}$.

\footnotetext{
${ }^{19}$ More generally, the auction has for any symmetrical differentiable cumulative distribution of values $F[\cdot]$ the solution $b[v]=\frac{1}{F[v]} \int_{0}^{v} z f[z] d z$ (e.g. Krishna, 2002).
} 
To calculate the reaction function of independent bidder $\mathrm{X}$, differentiate equation 2 with respect to $b_{X}$, set it equal to zero and solve for $y^{\prime}[b]$ :

5) $\quad y^{\prime}[b]=\frac{y[b]}{v_{x}-b}=\frac{y[b]}{x[b]-b}$.

Equations 4 and 5 form a system of differential equations that can be solved for $x[b]$ and $y[b]$ with the conditions that $x[\bar{b}]=y[\bar{b}]=1$ (a bidder makes the highest bid, $\bar{b}$, when he has the highest value, 1) and $x[0]=y[0]=0$ (a bidder makes the lowest bid, 0 , when he has the lowest, 0$).{ }^{20}$ After taking inverses, this gives us the bidding functions of $\mathrm{X}$ and $\mathrm{Y}$ for $0<v_{Y}, v_{X} \leq 1$ :

6) $b_{Y}\left[v_{Y}\right]=\frac{\sqrt{v_{Y}^{2}+a^{2}\left(1-v_{Y}^{2}\right)}-a}{\left(1-a^{2}\right) v_{Y}}$ with inverse $y[b]=\frac{2 a b}{1-b^{2}+a^{2} b^{2}}$

7) $b_{X}\left[v_{X}\right]=\frac{1-\sqrt{a^{2} v_{X}^{2}+\left(1-v_{X}^{2}\right)}}{\left(1-a^{2}\right) v_{X}}$ with inverse $x[b]=\frac{2 b}{1+b^{2}-a^{2} b^{2}}$.

The maximum bid $\bar{b}$ is equal to $\bar{b}=\frac{1}{(1+a)}$.

Setting cost weight $a$ smaller than unity makes Y bid more aggressively. In reaction to this, independent bidder $\mathrm{X}$ also bids more aggressively; an effect I will refer to as the interactive effect. Figure 5 shows the bidding functions for different $a<1$.

${ }^{20}$ A proof can be found in proposition 2 in the appendix. 
Figure 5

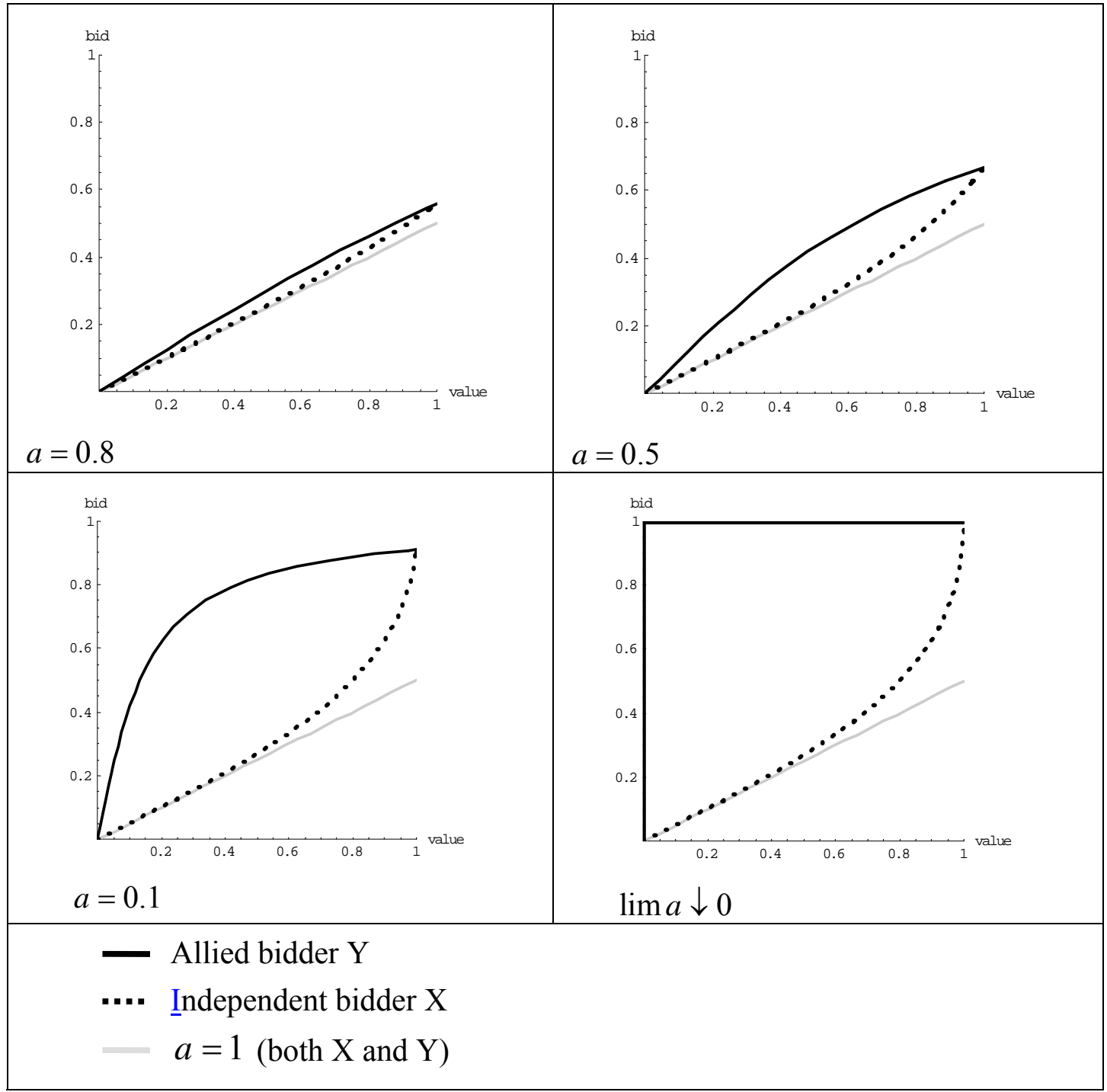

The more aggressive bidding strategies of $\mathrm{X}$ and $\mathrm{Y}$ have several noteworthy effects on the ex-ante expected auction outcomes: ${ }^{21}$

a. Allied bidder $\mathrm{Y}$ is more likely than before to win the auction.

b. Allied bidder $Y$ earns lower profits than before.

c. The compensation of manager $\mathrm{Y}^{\mathrm{m}}$ is higher than before.

d. The revenue of the auctioneer (or revenue from the auction) is higher than before and the revenue equivalence between first-price auctions and secondprice auctions does not hold. Revenue equivalence is upset by the interactive

\footnotetext{
${ }^{21}$ The formula and proofs can be found in proposition 3 in the appendix. I do not report the formula here as they do not add insightful information.
} 
effect - the independent bidder reacting to the more aggressive bidding of the allied bidder by also bidding more aggressively, because this effect only occurs in first-price auctions. Once the interaction effect is eliminated, revenue equivalence is restored.

A way to eliminate the interaction effect is by relaxing the first assumption ( $\mathrm{X}$ is informed of the compensation scheme) and supposing that $\mathrm{X}$ is ignorant (or skeptical) of the existence of the compensation scheme for manager $\mathrm{Y}^{\mathrm{m}} ; \mathrm{X}$ believes manager $\mathrm{Y}^{\mathrm{m}}$ to maximize the generation profits instead. Assume that $\mathrm{Y}^{\mathrm{m}}$ is aware of the ignorance of $\mathrm{X}$, so that $\mathrm{Y}^{\mathrm{m}}$ knows that $\mathrm{X}$ bids as in a symmetrical first-price auction. The bidding functions determined by $\mathrm{X}$ and $\mathrm{Y}^{\mathrm{m}}$ are in that case $b_{X}=\frac{v_{X}}{2}$ and $b_{Y}=\frac{v_{Y}}{2 a}$ and the expected auction revenue and profits are the same as those in the second-price auction. ${ }^{22}$ The ignorance (or skepticism) of bidder X, by eliminating the interactive effect, has reinstated revenue equivalence.

e. The profit of the holding company (i.e., the profit of both the auctioneer and the allied bidder) reaches a maximum at $a^{\mathrm{I} *} \approx 0.319$ of $\pi_{\text {Holding Company }}^{Y}\left[a^{\mathrm{I} *}\right] \approx 0.560-w^{0}$. Decreasing cost weight $a$ has three effects on the profit of the holding company. The first two effects are, like in second-price auctions, ownership effects. The third effect is an interaction effect that is unique to first-price auctions. Firstly, the aggressive bidding of Y makes Y win more auctions, thereby increasing the profit of the holding company. Secondly, for $a<$ 0.5 , Y overbids his value for all $v_{Y}$ such that $0<v_{Y}<{\sqrt{\frac{1-2 a}{1-a^{2}}}}^{23}$. This makes it more likely for $\mathrm{Y}$ to win the auction when the payment of $\mathrm{X}$ would have been

\footnotetext{
${ }^{22}$ A proof can be found in proposition 4 in the appendix.

${ }^{23}$ Given $a<0.5$, solving $0=v_{Y}^{0}-b_{Y}\left[v_{Y}^{0}\right]=v_{Y}^{0}-\frac{\sqrt{\left(v_{Y}^{0}\right)^{2}+a^{2}\left(1-\left(v_{Y}^{0}\right)^{2}\right)}-a}{\left(1-a^{2}\right) v_{Y}^{0}}$ for $v_{Y}^{0}$ results in $v_{Y}^{0}=\sqrt{\frac{1-2 a}{1-a^{2}}}$ and at this point the derivative $\frac{d\left(v_{Y}-b_{Y}\left[v_{Y}\right]\right)}{d v_{Y}}$ is positive.
} 
larger than the value of transmission for $\mathrm{Y}$, thereby decreasing the profit of the holding company. Thirdly, the interactive effect, $\mathrm{X}$ reacting to the more aggressive bidding of $\mathrm{Y}$ by also bidding more aggressively, tempers the first two effects. $^{24}$ Due to the interactive effect the optimum cost weight is lower than in second-price auctions; $a^{\mathrm{I} *} \approx 0.319<0.5=a^{\mathrm{II}} *$, and the maximum profit of the holding company is higher than in second-price auctions $\pi^{\text {COMPOUND }}\left[a^{\mathrm{I} *}\right] \approx 0.560-w^{0}>0.542-w^{0} \approx \pi^{\text {COMPOUND }}\left[a^{\mathrm{II} *}\right]$.

f. Independent bidder $\mathrm{X}$ earns lesser profits than before and at $a^{\mathrm{I} *} \approx 0.319$ $\pi_{\text {Generator }}^{X}\left[a^{\mathrm{I} *}\right] \approx 0.065<\frac{1}{6}=\pi_{\text {Generator }}^{X}[a=1]$.

g. The strategic profit of the holding company is positive and reaches a maximum of $\pi_{\text {Strategic }}^{Y}\left[a^{\mathrm{I} *}\right] \approx 0.060$, which is about $12 \%$ of total profits without a compensation scheme.

h. Welfare is lower than before; a welfare loss of the size of $\mathrm{WL}\left[a^{\mathrm{I} *}\right] \approx 0.0413$ occurs. This is a loss equal to about $6 \%$ of the optimum welfare (without a compensation scheme). Compared to the second-price auctions, the interaction effect (the independent bidder also bidding more aggressively), makes the auction relatively less asymmetric, thereby tempering the negative welfare effects. As a result the welfare loss is slightly lower for first-price auctions than for second-price auctions: $\mathrm{WL}\left[a^{\mathrm{I}} *\right] \approx 0.0413<0.0417=\mathrm{WL}\left[a^{\mathrm{II}} *\right]$.

\section{First mover's advantage}

In first-price auctions there is, in addition to the ownership effect we found in secondprice auctions, also an interactive effect in operation. The interactive effect is caused by the fact that bidders in first-price auctions, unlike those in second-price auctions, react to the strategies of the other bidder. In the analysis above the holding company is able to manipulate, by setting cost weight $a$ extra small, the interactive effect to its own benefit

\footnotetext{
${ }^{24}$ This interactive effect is the effect that Fershtman and Judd (1987) and Sklivas (1987) found and denote as the "strategic effect". The strategic effect I report for first-price auctions encompasses both the interaction effect and the ownership effect.
} 
thanks to its first mover's advantage. The first mover's advantage of the holding company only exists when the holding company can commit to its choice of compensation scheme. In the above case, this is guaranteed by the second assumption: "the rules on legal separation forbid the holding company to spread false information about the compensation scheme". Once the holding company has announced a particular compensation scheme, it is committed to it; any compensation scheme can therefore be part of a Nash equilibrium. A ban on providing false information gives the holding company in this way a first mover's advantage.

\section{Without first mover's advantage}

Once the second assumption is relaxed and the holding company is allowed, or otherwise able, to provide false information about the compensation scheme, then the holding company cannot credibly commit to just any compensation scheme. The first two steps in the timeline in Figure 4, $\mathrm{t} 1$ and $\mathrm{t} 2$ have now become a single step; the setting of the cost weight and the determination of the bidding functions is now done simultaneously and endogenously. The loss of its first mover's advantage results in less favorable auction outcomes for the holding company.

I calculate the Nash equilibrium cost weight by first supposing that the holding company announces a compensation scheme with cost weight $a$, and then, assuming that independent bidder $\mathrm{X}$ believes the announcement, maximizes its profits with a (possibly different) cost weight $q$. A Nash equilibrium exists if and only if the holding company announces a compensation scheme with cost weight $a^{N E}$ for which $q=\operatorname{ARGMAX}_{q}\left(\pi_{\text {Holding Company }}^{Y}\left[a^{N E}, q\right]\right)=a^{N E}$.

For any announced compensation scheme with cost weight $a$ that is believed by independent bidder $\mathrm{X}$, the bidding function of $\mathrm{X}$ is:

$b_{X}\left[v_{X} ; a\right]=\frac{1-\sqrt{a^{2} v_{X}{ }^{2}+\left(1-v_{X}{ }^{2}\right)}}{\left(1-a^{2}\right) v_{X}}$.

Manager $\mathrm{Y}$ then maximizes his profit given the bidding function of $\mathrm{X}, b_{X}\left[v_{X} ; a\right]$, and $q$, which results in 
$b_{Y}\left[v_{Y} ; a, q\right]=\frac{\sqrt{\left.v_{Y}^{2}+q^{2}-a^{2} v_{Y}^{2}\right)}-q}{\left(1-a^{2}\right) v_{Y}}$.

The holding company then sets $q$ to maximize its compound profit:

$q=\operatorname{ARGMAX}_{q}\left(\pi_{\text {Holding Company }}^{Y}[a, q)\right.$.

Numerical approximation for $a^{N E}$ such that $q=a^{N E}$ gives $a^{N E} \approx 0.361>0.319 \approx a^{I} * 25$. Total profit is slightly lower,

$\pi_{\text {Holding Company }}^{Y}\left[a^{N E}\right] \approx 0.5598-w^{0}<0.5603-w^{0} \approx \pi_{\text {Holding Company }}^{Y}\left[a^{*}\right]$ and so is the welfare loss, $\mathrm{WL}\left[a^{N E}\right] \approx 0.034<0.041 \approx \mathrm{WL}\left[a^{\mathrm{I} *}\right]$. While the results are slightly less pronounced, the qualitative results reported above remain.

\section{A first mover's advantage for the independent bidder?}

Just as a holding company, the owner of independent bidder X (owner X) can only implement a compensation scheme for its manager (manager $\mathrm{X}$ ) that constitutes a Nash equilibrium. It is generally true that whatever the strategies of the other players are, the best action for owner $\mathrm{X}$ is to have his profits maximized. Therefore, without means to credibly commit to a cost weight larger than unity (which implies not maximizing profits), the only Nash equilibrium strategy is for owner $\mathrm{X}$ to provide a compensation scheme with cost weight $s=1$ (see Dewatripont, 1988 and Katz, 1991).

For an illustration of this general principle, suppose that both the holding company and owner X had the opportunity to offer their managers compensation schemes and commit to it. The optimal choices of cost weights for both managers are then determined simultaneously; owner X would offer cost weight $s^{*} \approx 1.431$, which makes both bidders bid less aggressively, and the holding company would offer cost weight $\tilde{a} \approx 0.308<0.319 \approx a^{\mathrm{I}} *$, which makes both bidders bid more aggressively. The bidding functions of independent bidder $\mathrm{X}$ and allied bidder $\mathrm{Y}$ would be:

\footnotetext{
${ }^{25}$ I used a Mathematica program for approximation. The precise code can be downloaded from http://home.cerge-ei.cz/svk/Legally_separated.
} 
$b_{X}\left[v_{X} ; \tilde{a}, s^{*}\right]=\frac{\sqrt{s^{* 2}\left(1-v_{X}{ }^{2}\right)+\tilde{a}^{2} v_{X}{ }^{2}}-s^{*}}{\left(\tilde{a}^{2}-s^{* 2}\right) v_{X}}, b_{Y}\left[v_{Y} ; \tilde{a}, s^{*}\right]=\frac{\sqrt{\tilde{a}^{2}\left(1-v_{Y}{ }^{2}\right)+s^{* 2} v_{Y}{ }^{2}}-\tilde{a}}{\left(s^{* 2}-\tilde{a}^{2}\right) v_{Y}} .^{26}$

The maximum bid would be $\bar{b} \approx 0.575$. In this case, the profits of $X$ would increase to $\pi_{\text {Generator }}^{X}\left[\tilde{a}, s^{*}\right]=0.071>0.065=\pi_{\text {Generator }}^{X}\left[a^{\mathrm{I} *}, s=1\right] .^{27}$

However, owner X cannot credibly commit to this particular compensation scheme; he has the possibility to provide a (secret) side contract that sets $s=1$ (maximizing profits). Independent bidder $\mathrm{X}$ then finds his bidding function by maximizing his profits, given the above bidding function of $\mathrm{Y} ; b_{Y}\left[v_{Y} ; \tilde{a}, s^{*}\right]$. While $\mathrm{Y}$ would believe that $\mathrm{X}$ chooses the bidding function $b_{X}\left[v_{X} ; \tilde{a}, s^{*}\right]$ as described above, $\mathrm{X}$ chooses instead the bidding function:

$$
\frac{\sqrt{1-v_{X}^{2}+\tilde{a}^{* 2} v_{X}^{2}}-1}{\left(\tilde{a}^{* 2}-s^{2}\right) v_{X}} \quad \text { for } v_{X}<0.699
$$

$$
\text { for } v_{X}>0.699 \text {. }
$$

$\mathrm{X}$ then earns a profit of $\pi_{\text {Generator }}^{X}[\tilde{a}, s=1] \approx 0.105>0.071 \approx \pi_{\text {Generator }}^{X}\left[\tilde{a}, s^{*}\right]$. As this deviation is profitable for owner $\mathrm{X}$, him setting $s^{*}>1$ cannot be part of a Nash equilibrium.

\section{Partial ownership}

When the holding company does not fully own the auctioneer, but holds ownership share $\gamma$ in the auctioneer, then the holding company's profit is

$$
\pi_{\text {Holding Company }}^{Y}[a, \gamma]=\pi_{\text {Generator }}^{Y}[a]+\gamma m[a] \text {. }
$$

Maximizing the holding company's profit with respect to $a$ gives the optimal cost weight as a function of ownership share $\gamma$;

$$
a[\gamma]=\operatorname{ArgMax}_{\alpha}\left[\pi_{\text {Holding Company }}^{Y}[\alpha, \gamma]\right] .
$$

\footnotetext{
${ }^{26}$ These formulas are obtained by solving 4 ) and a likewise equation for the manager of allied bidder $\mathrm{X}$ with cost weight $s$.

${ }^{27}$ Other interesting auction outcomes would be that the profits of the holding company would fall, $\pi_{\text {Holding Company }}^{Y}[\tilde{a}] \approx 0.530-w^{0}<0.560-w^{0} \approx \pi_{\text {Holding Company }}^{Y}\left[a^{\mathrm{I} *}\right]$, and that, as the auction would be more asymmetric, the welfare loss would increase, $\mathrm{WL}\left[\tilde{a}, s^{*}\right] \approx 0.065>0.041 \approx \mathrm{WL}\left[a^{\mathrm{I} *}, s=1\right]$.
} 
Figure 5 shows the optimal cost weight, $a[\gamma]$ for ownership shares $\gamma$ between zero and one $^{28}$ for first-price (both with and without a first movers' advantage) and second-price auctions.

Figure 5

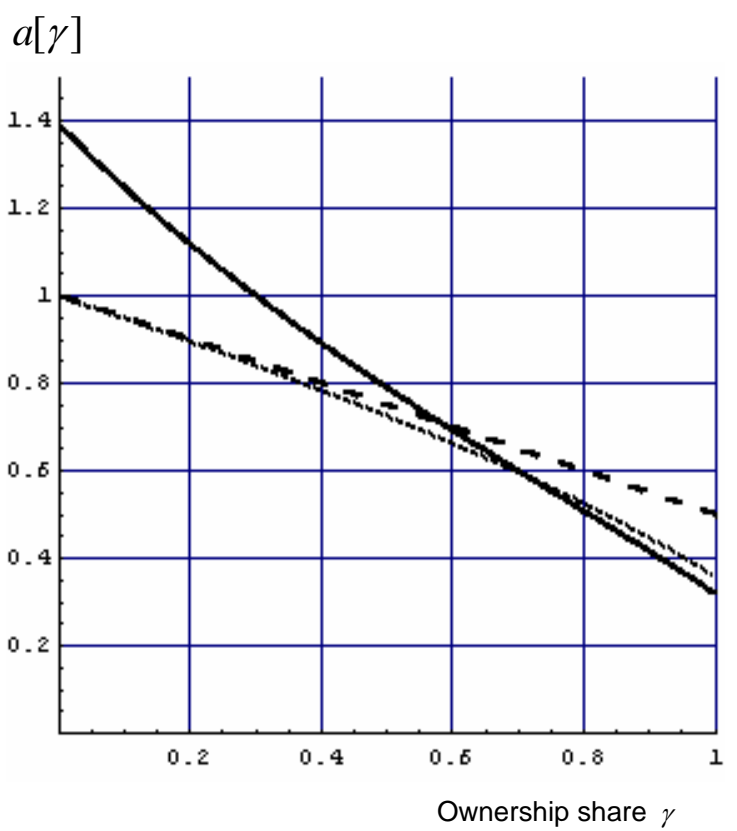

_ first-price auction (first mover's advantage)

..... first-price auction (without first mover's advantage)

.. second-price auction

When the ownership share of the auctioneer is small, $\gamma<0.3$, the holding company with a first mover's advantage in first-price auctions sets the cost weight higher than unity to make $\mathrm{Y}$ bid less aggressively and to lower the auction revenue. This is profitable because of the interaction effect in first-price auctions; by making Y a "fat cat" by overstating the costs of bidding (Fudenberg and Tirole, 1984), the competing independent bidder reacts by also bidding less aggressively which lowers the bidding costs for both bidders ${ }^{29}$. The negative effect this has through lower auction revenues is of little importance as the holding company has a low ownership share $\gamma<0.3$. The less

\footnotetext{
${ }^{28}$ The values for $a[\gamma]$ in first-price auctions have been obtained by numerical approximation.

${ }^{29}$ This effect is comparable to the "fat cat" effect in Bertrand competition found in Fershtman and Judd (1987) and Sklivas (1987).
} 
aggressive bidding increases both the strategic profit and the welfare loss when the ownership share goes to zero.

When the ownership share of the auctioneer is large or medium, $\gamma>0.3$, the holding company sets the cost weight lower than unity to make Y bid more aggressively and to increase the auction revenue. For large ownership shares, $\gamma>0.6$, the holding company sets a lower cost weight in first-price auctions than in second-price auctions. Due to the interaction effect in first-price auctions, the independent bidder also bids more aggressively which decreases the asymmetry of the auction and thereby makes lowering the cost weight less costly for the holding company.

The holding company without a first mover's advantage cannot strategically use the interaction effect in first-price auctions and in second-price auctions, no interaction effect exists. Therefore, in these cases, the cost weight is equal to unity for no ownership, $\gamma=0$, and for $0 \leq \gamma \leq 1$ a strictly decreasing function of the ownership share $\gamma$. Figure 6 illustrates the effects on strategic profits and welfare losses.

Note that a holding company without a first mover's advantage receives negative strategic profits. Legal separation of the generator from the VIU without a ban on spreading false information about the compensation scheme becomes a burden for a holding company that owns less than $40 \%$ of transmission. After that the strategic profit fairly resembles the first-price auction with a first movers' advantage.

When the holding company has no first mover's advantage, then the first-price auction is to be preferred above the second-price auction - the welfare loss is smaller than in the second-price auction. When the holding company has a first mover's advantage, then the first-price auction is still to be preferred as long as the holding company owns more than $17 \%$ of the transmission. When the holding company owns less than $17 \%$ of the transmission, the second-price auction is to be preferred. 
Figure 6

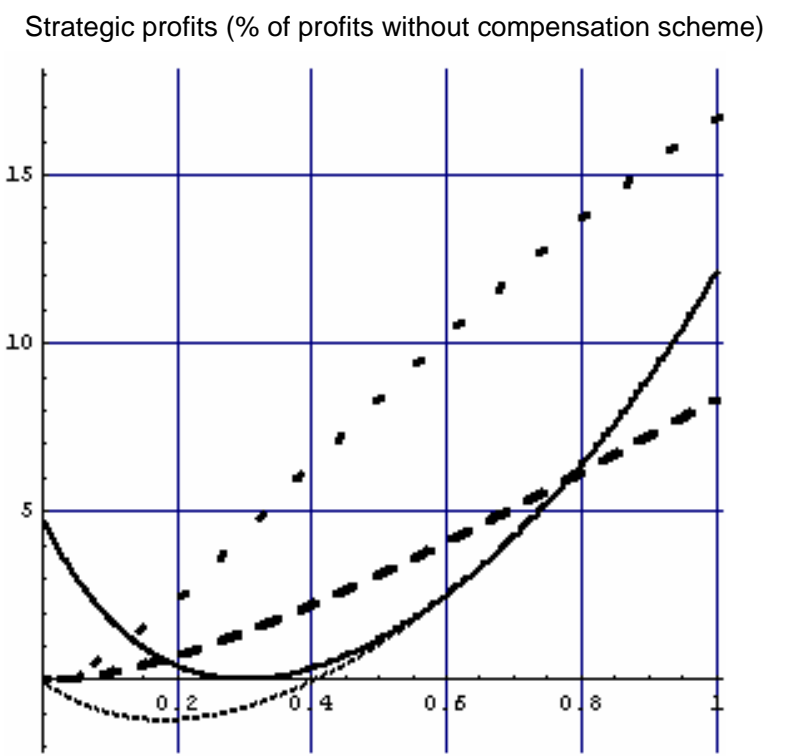

Ownership share $\gamma$

$$
\pi_{\text {Strategic }}^{Y}[a[\gamma], \gamma]
$$

_ first-price auction (first movers' advantage)

...... first-price auction (without first movers' advantage)

... second-price auction

- - second-price auction $\mathrm{ABK}$

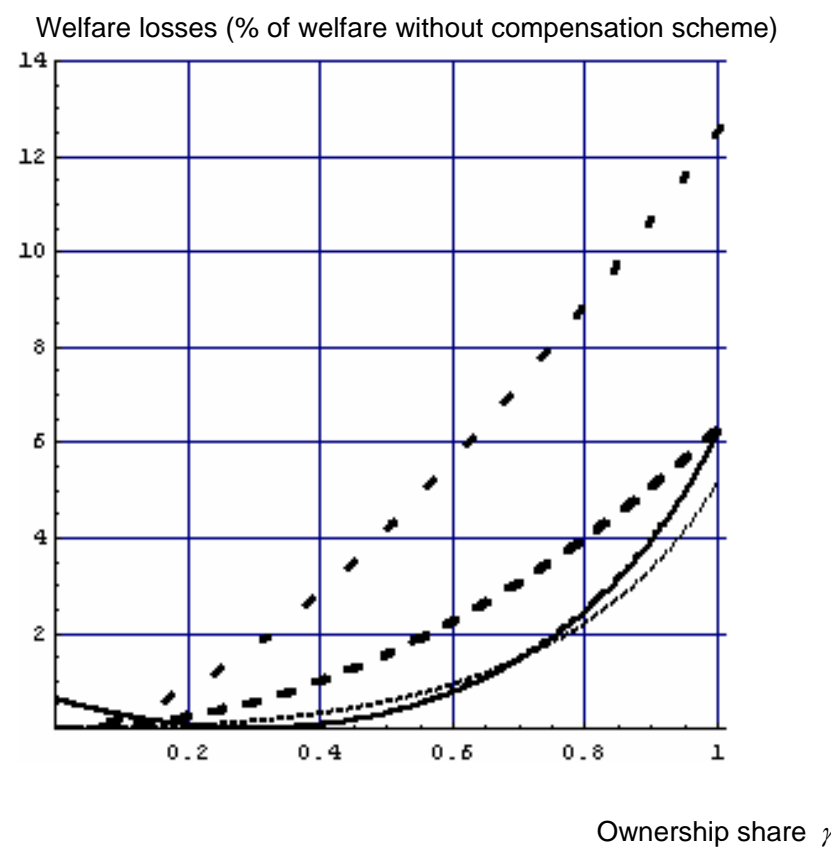

$W[a[\gamma]]$

_ first-price auction (first movers' advantage) first-price auction (without first movers' advantage)

- second-price auction

- - second-price auction ABK

For comparison I have also included the results from Van Koten (2006) when the holding company can order its allied generator to maximize the total holding profits by help of the Any-Bid-Kickback scheme (ABK). It shows that the legal separation of the generator tempers both the size of the strategic profit and the welfare loss. However, from the above analysis of legally separating the generator two points can be made. Firstly, the OBK scheme is likely to be used as it either results in a positive strategic profit (in the case of second-price auctions and first-price auctions with first mover's advantage) or it is the only Nash equilibrium (in the case of first-price auctions without first mover's advantage). Secondly, using the OBK scheme generally incurs a considerable welfare loss. ${ }^{30}$

\footnotetext{
${ }^{30}$ except when the holding company owns about $30 \%$ of transmission in a first-price auction with first mover's advantage
} 


\section{Discussion}

In an earlier paper, Van Koten (2006), I showed that a holding company that owns an unregulated transmission line could increase its profits by having its bidder follow the Any-Bid-Kickback scheme (ABK scheme). The ABK scheme consists of the bidder taking into account the full effect of his bidding on the transmission auction revenue and makes the bidder bid more aggressively. In turn, this increases the price of transmission, increases the profits of the holding company, and lowers welfare.

In the present paper, I explore in a similar setup to which extent the legal separation of the bidder from the holding company could improve welfare. When the bidder is legally separated, the holding company cannot implement a compensation scheme to maximize the profits of the overall holding company. ${ }^{31}$ This rules out application of the ABK scheme. However, the OBK scheme analyzed in this paper respects the legal separation; the OBK compensation scheme is based on performance indicators of the bidder only. By implementing the OBK kickback scheme, the holding company is able to mimic the workings of the ABK scheme to a considerable degree.

For illustration I make a rough estimate of the welfare cost in the scenario where a holding company who fully owns a generator in Germany builds a merchant transmission line connecting Germany and the Netherlands. I assume that the total auction revenue, 123.4 million Euro (CONSENTEC, 2004, p.A3) on the existing line between Germany and the Netherlands in 2003 is a representative number and that the new merchant transmission line extends the existing capacity by $20 \%$. I estimate that the economic size of the transmission line is then about 25 million Euro a year $(20 \%$ of 123.4 million Euro). By using the OBK scheme, the holding company would then be able to earn a strategic profit of 2 million Euro a year ( $8 \%$ ) and incur a welfare loss of 1.5 million Euro a year (6\%). As the EU has 29 more border crossings and as the need for more interconnection is growing, this scenario could become a reality on a larger scale, implying even higher welfare losses.

\footnotetext{
${ }^{31}$ I assume here that legal separation is effective. In cases where it is likely that violations of the restrictions imposed by legal separation go unpunished, the holding company can freely instruct the allied bidder to maximize the profits of the holding company. I show in Van Koten (2006) that the qualitative outcomes remain unchanged (the holding company profits, welfare suffers).
} 


\section{Conclusions}

My analysis suggests that, for two prominent auction formats, a holding company that is legally unbundled (but ownership integrated) can nonetheless provide the manager of its legally unbundled generator with incentives to bid more aggressively by means of a simple but well-chosen OBK compensation scheme. The OBK scheme does not refer to performance indicators outside of the generator and therefore fully respects the legal separation between the allied generator, the holding company, and the transmission auctioneer.

The OBK compensation scheme, which can be used with a legally unbundled generator, can trigger an aggressiveness of bidding that increases the profit of the holding company and causes a welfare loss. While the increase of the profit and the welfare loss are considerable, they are less than under the ABK scheme which can be used with a legally integrated generator. Legal separation of the generator therefore does improve welfare, but not to the same extent as ownership unbundling. This suggests that the regulatory measure of legal unbundling of the generator is unsatisfactory.

This result should be of interest to regulators of the EU electricity industry, as they might consider applying legal unbundling of the generator to remedy problems of abuse of market power by holding companies. The result is especially relevant when unregulated for-profit building of transmission lines is allowed to address the issue of underinvestment in interconnector capacity. My model shows that legal unbundling of the generator is not likely to bring much improvement. In this setting, auctions lose their favorable features (non-discriminatory, market-based and efficient) and holding companies are therefore likely not to allocate transmission capacity in a nondiscriminatory and efficient manner.

My model does suggest that ownership unbundling provides a remedy. Once the holding company is not a residual claimant of the auction revenue any more, it loses the incentive to have its allied generator bid excessively aggressively. 


\section{Appendix}

\section{Proposition 1}

a. The probability of winning for allied bidder $Y, P^{Y \text { wins }}[a]=\frac{2-a}{2}$, is strictly decreasing in cost weight $a$.

b. The profit of allied bidder $\mathrm{Y}, \pi_{\text {Generator }}^{Y}[a]=\frac{a(2-a)}{6}-w^{0}$, is strictly increasing in cost weight $a$ for $a<1$.

c. The compensation of manager $\mathrm{Y}^{\mathrm{m}}, \pi_{\text {Manager }}^{Y}[a]=i \cdot \frac{a^{2}-3 a+3}{6}$, is strictly decreasing in $a$ for $a<1$ and given $i$.

d. The auction revenue, $m[a]=\frac{3-a}{6}$, is strictly decreasing in cost weight $a$.

e. The profit of the holding company, $\pi_{\text {Holding Company }}^{Y}[a]=\frac{3+a(1-a)}{6}-w^{0}$, reaches an optimum for $a^{\mathrm{II}} *=\frac{1}{2}$.

f. The profit of independent bidder $X, \pi^{X}[a]=\frac{a}{6}$, is strictly increasing in cost weight $a$.

g. The strategic profit of $\mathrm{Y}, \pi_{\text {Strategic }}^{Y}[a]=\frac{a(1-a)}{6}$, reaches an optimum for $a^{\mathrm{II} *}=\frac{1}{2}$.

h. The welfare, $W[a]=\frac{(3-a)(1+a)}{6}$, is strictly increasing in cost weight $a$ for $a<1$.

\section{Proofs:}

a. The probability of winning for allied bidder $Y, P^{Y \text { wins }}[a]=\frac{2-a}{2}$, is strictly decreasing in cost weight $a$.

Proof:

The probability that $\mathrm{Y}$ wins is as follows,

$$
P^{Y \text { wins }}\left[v_{y} ; a\right]=1 \quad \text { if } v_{y} \geq a
$$




$$
=\frac{v_{y}}{a} \quad \text { if } v_{y}<a .
$$

The ex-ante expected probability of winning, $P^{Y \text { wins }}[a]$, is $P^{Y \text { wins }}\left[v_{y} ; a\right]$ integrated over all possible realizations of $v_{y}$;

$$
\begin{aligned}
P^{Y \text { wins }}[a] & =\int_{0}^{a} P^{Y \text { wins }}\left[v_{Y} ; a \mid v_{Y}<a\right] \cdot d v_{y}+\int_{a}^{1} P^{Y \text { wins }}\left[v_{Y} ; a \mid v_{Y} \geq a\right] d v_{Y} \\
& =\int_{0}^{a} \frac{v_{Y}}{a} d v_{Y}+\int_{a}^{1} 1 d v_{Y} \\
& =\left[\frac{v_{Y}^{2}}{2 a}\right]_{0}^{a}+\left[v_{Y}\right]_{a}^{1} \\
& =\frac{a}{2}+(1-a) \\
& =\frac{2-a}{2} .
\end{aligned}
$$

b. The profit of allied bidder $\mathrm{Y}, \pi_{\text {Generator }}^{Y}[a]=\frac{a(2-a)}{6}-w^{0}$, is strictly increasing in cost weight $a$ for $a<1$.

Proof:

$$
\begin{aligned}
\pi_{\text {Generator }}^{Y}[a] & =\int_{0}^{a} \frac{v_{Y}}{a}\left(v_{Y}-E\left[b_{X} \mid b_{X}<b_{Y}\right]\right) d v_{Y}+\int_{a}^{1}\left(v_{Y}-E\left[b_{X}\right]\right) d v_{Y}-w^{0} \\
& =\int_{0}^{a} \frac{v_{Y}}{a}\left(v_{Y}-E\left[v_{X} \mid v_{X}<\frac{v_{Y}}{a}\right]\right) d v_{Y}+\int_{a}^{1}\left(v_{Y}-E\left[v_{X}\right]\right) d v_{Y}-w^{0} \\
& =\int_{0}^{a} \frac{v_{Y}}{a}\left(v_{Y}-\frac{v_{Y}}{2 a}\right) d v_{Y}+\int_{a}^{1}\left(v_{Y}-\frac{1}{2}\right) d v_{Y}-w^{0} \\
& =\int_{0}^{a} v_{Y}^{2}\left(\frac{2 a-1}{2 a^{2}}\right) d v_{Y}+\int_{a}^{1}\left(v_{Y}-\frac{1}{2}\right) d v_{Y}-w^{0} \\
& =\left[v_{Y}^{3}\left(\frac{2 a-1}{6 a^{2}}\right)\right]_{0}^{a}+\left[\frac{v_{Y}^{2}}{2}-\frac{v_{Y}}{2}\right]_{a}^{1}-w^{0} \\
& =\frac{a(2 a-1)}{6}+\frac{a}{2}-\frac{a^{2}}{2}-w^{0} \\
& =\frac{a(2-a)}{6}-w^{0} .
\end{aligned}
$$


c. The compensation of manager $\mathrm{Y}^{\mathrm{m}}, \pi_{\text {Manager }}^{\mathrm{Y}}[a]=i \cdot \frac{a^{2}-3 a+3}{6}$, is strictly decreasing in $a$ for $a<1$ and given i.

Proof:

$$
\begin{aligned}
\frac{\pi_{\text {Manager }[a]}^{Y}[a]}{i} & =\int_{0}^{a} \frac{v_{Y}}{a}\left(v_{Y}-a E\left[b_{X} \mid b_{X}<b_{Y}\right]\right) d v_{Y}+\int_{a}^{1}\left(v_{Y}-a E\left[b_{X}\right]\right) d v_{Y} \\
& =\int_{0}^{a} \frac{v_{Y}}{a}\left(v_{Y}-a E\left[v_{X} \mid v_{X}<\frac{v_{Y}}{a}\right]\right) d v_{Y}+\int_{a}^{1}\left(v_{Y}-a E\left[v_{X}\right]\right) d v_{Y} \\
& =\int_{0}^{a} \frac{v_{Y}}{a}\left(v_{Y}-a \frac{v_{Y}}{2 a}\right) d v_{Y}+\int_{a}^{1}\left(v_{Y}-\frac{a}{2}\right) d v_{Y} \\
& =\int_{0}^{a} \frac{v_{Y}^{2}}{2 a} d v_{Y}+\int_{a}^{1}\left(v_{Y}-\frac{a}{2}\right) d v_{Y} \\
& =\left[\frac{v_{Y}^{3}}{6 a}\right]_{0}^{a}+\left[\frac{v_{Y}^{2}}{2}-\frac{a v_{Y}}{2}\right]_{a}^{1} \\
& =\frac{a^{3}}{6 a}+\frac{1}{2}-\frac{a}{2} \\
& =\frac{a^{2}-3 a+3}{6} .
\end{aligned}
$$

d. The auction revenue, $m[a]=\frac{3-a}{6}$, is strictly decreasing in cost weight $a$.

Proof: The ex-ante net expected revenue of the auctioneer is

$$
\begin{aligned}
m[a] & =m^{X}[a]+\left(m^{Y}[a]\right) \\
& \left.=\int_{0}^{1} a v_{X} \cdot E\left[b_{Y} \mid b_{Y}<b_{X}\right]\right) d v_{X}+\left(\int_{0}^{a} \frac{v_{Y}}{a} \cdot E\left[b_{X} \mid b_{X}<b_{Y}\right] d v_{Y}+\int_{a}^{1} 1 \cdot E\left[b_{X}\right] d v_{Y}\right) \\
& \left.=\int_{0}^{1} a v_{X} \cdot E\left[\frac{v_{Y}}{a} \mid v_{Y}<a v_{X}\right]\right) d v_{X}+\left(\int_{0}^{a} \frac{v_{Y}}{a} \cdot E\left[v_{X} \mid v_{X}<\frac{v_{Y}}{a}\right] d v_{Y}+\int_{a}^{1} 1 \cdot E\left[v_{X}\right] d v_{Y}\right) \\
& =\int_{0}^{1} a v_{X} \cdot \frac{a v_{X}}{2 a} d v_{X}+\left(\int_{0}^{a} \frac{v_{Y}}{a} \cdot \frac{v_{Y}}{2 a} d v_{Y}+\int_{a}^{1} \frac{1}{2} d v_{Y}\right) \\
& =\int_{0}^{1} \frac{a v_{X}^{2}}{2} d v_{X}+\left(\int_{0}^{a} \frac{v_{Y}^{2}}{2 a^{2}} d v_{Y}+\int_{a}^{1} \frac{1}{2} d v_{Y}\right)
\end{aligned}
$$




$$
\begin{aligned}
& =\left[\frac{a v_{X}^{3}}{6}\right]_{0}^{1}+\left(\left[\frac{v_{Y}^{3}}{6 a^{2}}\right]_{0}^{a}+\left[\frac{v_{Y}}{2}\right]_{a}^{1}\right) \\
& =\frac{a}{6}+\left(\frac{3-2 a}{6}\right) \\
& =\frac{3-a}{6} .
\end{aligned}
$$

e. The profit of the holding company, $\pi_{\text {Holding Company }}^{Y}[a]=\frac{3+a(1-a)}{6}-w^{0}$, reaches an optimum for $a^{\mathrm{II} *}=\frac{1}{2}$.

Proof:

$$
\begin{aligned}
\pi_{\text {Holding Company }}^{Y}[a]= & m[a]+\pi_{\text {Generator }}^{Y}[a] \\
& =\frac{3-a}{6}+\frac{a(2-a)}{6}-w^{0} \\
& =\frac{3+a(1-a)}{6}-w^{0} .
\end{aligned}
$$

f. The profit of the independent bidder $X, \pi^{X}[a]=\frac{a}{6}$, is strictly increasing in cost weight $a$

Proof :

The ex-ante expected profit of $X$ is equal to:

$$
\begin{aligned}
\pi_{\text {Generator }}^{X}[a] & =\int_{0}^{1} a v_{X}\left(v_{X}-E\left[b_{Y} \mid b_{Y}<b_{X}\right]\right) d v_{X} \\
& =\int_{0}^{1} a v_{X}\left(v_{X}-E\left[\frac{v_{Y}}{a} \mid v_{Y}<a v_{X}\right]\right) d v_{X} \\
& =\int_{0}^{1} a v_{X}\left(v_{X}-\frac{a v_{X}}{2 a}\right) d v_{X} \\
& =\int_{0}^{1} \frac{a v_{X}^{2}}{2} d v_{X} \\
& =\left[\frac{a v_{X}^{3}}{6}\right]_{0}^{1} \\
& =\frac{a}{6} .
\end{aligned}
$$


g. The strategic profit of $\mathrm{Y}, \pi_{\text {Strategic }}^{Y}[a]=\frac{a(1-a)}{6}$, reaches an optimum for $a^{\mathrm{II} *}=\frac{1}{2}$.

Proof:

$$
\begin{aligned}
& \pi_{\text {Strategic }}^{Y}[a]=\pi_{\text {Generator }}^{Y}[a]+m[a]-\left(\pi_{\text {Generator }}^{Y}[1]+m[1]\right) \\
& =\frac{a(2-a)}{6}-w^{0}+\frac{3-a}{6}-\left(\frac{1}{6}-w^{0}+\frac{2}{6}\right) \\
& =\frac{a(1-a)}{6} .
\end{aligned}
$$

Which is maximized for $a=\frac{1}{2}$.

h. The welfare, $W[a]=\frac{(3-a)(1+a)}{6}$, is strictly increasing in cost weight $a$ for $a<1$.

Proof:

$$
\begin{aligned}
& \begin{aligned}
W[a] & =\pi_{\text {Generator }}^{Y}[a]+\pi^{X}[a]+m[a]+w^{0}= \\
& =\frac{a(2-a)}{6}-w^{0}+\frac{a}{6}+\frac{1}{2}-\frac{a}{6}+w^{0} \\
& =\frac{3+a(2-a)}{6} \\
& =\frac{(3-a)(1+a)}{6} . \\
\frac{d W[a]}{d a} & =\frac{1-a}{3}>0 .
\end{aligned}
\end{aligned}
$$

\section{Proposition 2}

The bidding functions of $\mathrm{X}$ and $\mathrm{Y}$ are

6) $b_{Y}\left[v_{Y}\right]=\frac{\sqrt{v_{Y}^{2}+a^{2}\left(1-v_{Y}^{2}\right)}-a}{\left(1-a^{2}\right) v_{Y}}$ with inverse $y[b]=\frac{2 a b}{1-b^{2}+a^{2} b^{2}}$

7) $b_{X}\left[v_{X}\right]=\frac{1-\sqrt{a^{2} v_{X}^{2}+\left(1-v_{X}^{2}\right)}}{\left(1-a^{2}\right) v_{X}}$ with inverse $x[b]=\frac{2 b}{1+b^{2}-a^{2} b^{2}}$.

The maximum bid $\bar{b}$ is equal to $\bar{b}=\frac{1}{(1+a)}$. 


\section{Proofs:}

Solving 4) and 5), we will use the constraints

$$
\begin{aligned}
& x[0]=y[0]=0 \quad \text { (a bidder with value zero bids zero). } \\
& x[\bar{b}]=y[\bar{b}]=1, \text { where } \bar{b} \text { is the maximum bid } 0<\bar{b}<1
\end{aligned}
$$

(a bidder with value 1 bids a unique maximal bid).

Rewriting 4) and 5) gives

$$
\begin{aligned}
& \text { 9) } \quad\left(x^{\prime}[b]-1\right) \cdot(y[b]-a b)=a x[b]-y[b]+a b \\
& y^{\prime}[b] \cdot(x[b]-b)=y[b] \Leftrightarrow \\
& \text { 10) }\left(y^{\prime}[b]-a\right) \cdot(x[b]-b)=y[b]-a x[b]+a b \text {. }
\end{aligned}
$$

Adding up 9) and 10) gives

$$
\left(x^{\prime}[b]-1\right) \cdot(y[b]-a b)+(x[b]-b) \cdot\left(y^{\prime}[b]-a\right)=2 a b \Leftrightarrow
$$

11) $\frac{\partial}{\partial b}(x[b]-b) \cdot(y[b]-a b)=2 a b$.

Integrating equation c) over 0 until the maximum bid $\bar{b}$ using $x[0]=y[0]=0$ gives

$$
\begin{aligned}
& (1-\bar{b}) \cdot(1-a \bar{b})=a \bar{b}^{2} \Leftrightarrow \\
& 1+a \bar{b}^{2}-(1+a) \bar{b}=a \bar{b}^{2} .
\end{aligned}
$$

Therefore the maximum bid $\bar{b}$ is given by

12) $\quad \bar{b}=\frac{1}{(1+a)}$.

Integrating equation 11) over 0 until $b$ using $x[0]=y[0]=0$ gives

13) $(x[b]-b) \cdot(y[b]-a b)=a b^{2}$.

Applying 13) to 5) and 6) gives 
$\begin{aligned} \text { 14) } \quad x^{\prime}[b] & =\frac{x[b](x[b]-b)}{b^{2}} \\ \text { 15) } \quad y^{\prime}[b] & =\frac{y[b](y[b]-a b)}{a b^{2}}\end{aligned}$

Using 12) substituted into the condition $x[\bar{b}]=y[\bar{b}]=1,14)$ and 15) can be shown to have the solutions 16) and 17)

16) $x[b]=\frac{2 b}{1+b^{2}-a^{2} b^{2}}$

17) $y[b]=\frac{2 a b}{1-b^{2}+a^{2} b^{2}}$.

Taking inverses gives us the optimal pure bidding strategies 6) and 7):

6) $b_{Y}\left[v_{Y}\right]=\frac{\sqrt{a^{2}+v_{Y}{ }^{2}-a^{2} v_{Y}{ }^{2}}-a}{v_{Y}-a^{2} v_{Y}}$

7) $b_{X}\left[v_{X}\right]=\frac{1-\sqrt{1-v_{X}^{2}+a^{2} v_{X}^{2}}}{v_{X}-a^{2} v_{X}}$.

\section{Proposition 3}

a. The probability of winning for allied bidder $Y, p^{Y \text { wins }}[a]=\frac{1}{1+a}$, is strictly decreasing in cost weight $a$.

b. The profit of allied bidder Y,

$$
\pi_{\text {Generator }}^{Y}[a]=\frac{(2-a) \operatorname{ArcCsch}\left(\frac{a}{\sqrt{1-a^{2}}}\right)-\sqrt{1-a^{2}}}{2\left(1-a^{2}\right)^{\frac{3}{2}}}-w^{0}, \text { is strictly increasing in cost }
$$

weight $a$ for $a<1$.

c. The compensation of manager $\mathrm{Y}^{\mathrm{m}}$,

$$
\pi_{\text {Manager }}^{Y}[a]=i \cdot \frac{1}{2-2 a^{2}}\left(1-2 a+\frac{a^{2} \operatorname{ArcCsch}\left(\frac{a}{\sqrt{1-a^{2}}}\right)}{\sqrt{1-a^{2}}}\right) \text {, is strictly decreasing in cost }
$$


weight $a$ for $a<1$.

d. The auction revenue,

$$
m[a]=\left(\frac{1}{\left(1-a^{2}\right)}-\frac{a \cdot \operatorname{ArcCsch}\left(\frac{a}{\sqrt{1-a^{2}}}\right)}{\left(1-a^{2}\right)^{\frac{3}{2}}}\right)+a\left(\frac{1}{a^{2}-1}-\frac{\operatorname{ArcSinh}\left(\sqrt{a^{2}-1}\right)}{\left(a^{2}-1\right)^{\frac{3}{2}}}\right) \text {, is strictly }
$$

decreasing in cost weight $a$ for $a<1$.

e. The profit of the holding company,

$$
\begin{aligned}
\pi_{\text {Holding Company }}^{Y}[a] & =\frac{\sqrt{1-a^{2}}-(2-a) a \operatorname{ArcCsch}\left(\frac{a}{\sqrt{1-a^{2}}}\right)}{2\left(1-a^{2}\right)^{\frac{3}{2}}}-w^{0} \\
& +\gamma\left(\frac{1}{\left(1-a^{2}\right)}-\frac{a \cdot \operatorname{ArcCsch}\left(\frac{a}{\sqrt{1-a^{2}}}\right)}{\left(1-a^{2}\right)^{\frac{3}{2}}}-a\left(\frac{\operatorname{ArcSinh}\left(\sqrt{a^{2}-1}\right)}{\left(a^{2}-1\right)^{\frac{3}{2}}}+\frac{1}{1-a^{2}}\right)\right.
\end{aligned}
$$

$\pi_{\text {Holding Company }}^{Y}[a]=\frac{3+a(1-a)}{6}-w^{0}$, reaches an optimum for $a^{\mathrm{I} *} \approx 0.319404$. The profit is then $\pi^{\text {COMPOUND }}\left[a^{\mathrm{I} *}\right] \approx 0.560315-w^{0}$.

f. The profit of independent bidder $\mathrm{X}$,

$$
\pi_{\text {Generator }}^{X}[a]=\frac{a\left((a-2) \sqrt{-1+a^{2}}+\operatorname{ArcSinh}\left(\sqrt{a^{2}-1}\right)\right)}{2\left(-1+a^{2}\right)^{\frac{3}{2}}} \text {, is strictly increasing in cost }
$$

weight $a$ for $a<1$.

g. The strategic profit of the holding company is positive and reaches a maximum of $\pi_{\text {Strategic }}^{Y}\left[a^{\mathrm{I} *}\right] \approx 0.060$. 
h. The welfare, $W[a]=\frac{1}{2}\left(1-\frac{a^{2} \operatorname{ArcCsch}\left(\frac{a}{\sqrt{1-a^{2}}}\right)}{\left(1-a^{2}\right)^{\frac{3}{2}}}-\frac{a \operatorname{ArcSinh}\left(\sqrt{a^{2}-1}\right)}{\left(a^{2}-1\right)^{\frac{3}{2}}}\right)$, is strictly increasing in cost weight $a$ for $a<1$.

\section{Proofs:}

a. The probability of winning for allied bidder $Y, p^{Y \text { wins }}[a]=\frac{1}{1+a}$, is strictly decreasing in cost weight $a$.

Proof:

Using propositions 1 and 4, it follows that allied bidder $\mathrm{Y}$ with a realized value of $v_{y}$ wins with probability

$$
x \circ b_{Y}\left[v_{Y} ; a\right]=\frac{v_{Y}}{\sqrt{v_{Y}^{2}+a^{2}\left(1-v_{Y}^{2}\right)}} .
$$

The expected proportion of auctions that is won by allied bidder $\mathrm{Y}$ is then

$$
\begin{aligned}
p^{Y \text { wins }}[a] & =\int_{0}^{1} x \circ b_{Y}\left[v_{Y} ; a\right] d v_{Y} \\
& =\int_{0}^{1} \frac{v_{Y}}{\sqrt{v_{Y}^{2}+a^{2}\left(1-v_{Y}{ }^{2}\right)}} d v_{Y} \\
& =\frac{1}{1+a} .
\end{aligned}
$$

b. The profit of allied bidder $Y$,

$$
\pi_{\text {Generator }}^{Y}[a]=\frac{(2-a) \operatorname{ArcCsch}\left(\frac{a}{\sqrt{1-a^{2}}}\right)-\sqrt{1-a^{2}}}{2\left(1-a^{2}\right)^{\frac{3}{2}}}-w^{0}, \text { is strictly increasing in cost }
$$

weight $a$ for $a<1$.

Proof:

The profit of allied bidder $\mathrm{Y}$ is 


$$
\begin{aligned}
\pi_{\text {Generator }}^{Y}[a]= & \int_{0}^{1} x \circ b_{Y}\left[v_{Y} ; a\right] \cdot\left(v_{Y}-b_{Y}\left[v_{Y} ; a\right]\right) d v_{Y}-w^{0} \\
& =\int_{0}^{1} \frac{v_{Y}}{\sqrt{v_{Y}^{2}+a^{2}\left(1-v_{Y}^{2}\right)}} \cdot\left(v_{Y}-\frac{\sqrt{a^{2}+v_{Y}^{2}-a^{2} v_{Y}^{2}}-a}{v_{Y}-a^{2} v_{Y}}\right) d v_{Y}-w^{0} \\
& =\frac{(2-a) \operatorname{ArcCsch}\left(\frac{a}{\sqrt{1-a^{2}}}\right)-\sqrt{1-a^{2}}}{2\left(1-a^{2}\right)^{\frac{3}{2}}}-w^{0} .
\end{aligned}
$$

This expression is increasing in cost weight $a$ for $\frac{d \pi_{\text {Generator }}^{Y}[a]}{d a}>0$ has been determined numerically.

c. The compensation of manager $\mathrm{Y}^{\mathrm{m}}$,

$$
\pi_{\text {Manager }}^{Y}[a]=i \cdot \frac{1}{2-2 a^{2}}\left(1-2 a+\frac{a^{2} \operatorname{ArcCsch}\left(\frac{a}{\sqrt{1-a^{2}}}\right)}{\sqrt{1-a^{2}}}\right) \text {, is strictly decreasing in cost }
$$

weight $a$ for $a<1$.

Proof:

$$
\begin{aligned}
\frac{\pi_{\text {Manager }}^{Y}[a]}{i} & =\int_{0}^{1} x \circ b_{Y}\left[v_{Y} ; a\right] \cdot\left(v_{Y}-a b_{Y}\left[v_{Y} ; a\right]\right) d v_{Y} \\
& =\int_{0}^{1} \frac{v_{Y}}{\sqrt{v_{Y}^{2}+a^{2}\left(1-v_{Y}^{2}\right)}}\left(v_{Y}-a \frac{\sqrt{a^{2}+v_{Y}^{2}-a^{2} v_{Y}^{2}}-a}{v_{Y}-a^{2} v_{Y}}\right) d v_{Y} \\
& =\frac{1}{2-2 a^{2}}\left(1-2 a+\frac{a^{2} \operatorname{ArcCsch}\left(\frac{a}{\sqrt{1-a^{2}}}\right)}{\sqrt{1-a^{2}}}\right) .
\end{aligned}
$$

$\frac{d \pi_{\text {Manager }}^{Y}[a]}{d a}<0$ has been determined numerically.

d. The auction revenue, 
$m[a]=\left(\frac{1}{\left(1-a^{2}\right)}-\frac{a \cdot \operatorname{ArcCsch}\left(\frac{a}{\sqrt{1-a^{2}}}\right)}{\left(1-a^{2}\right)^{\frac{3}{2}}}\right)+a\left(\frac{1}{a^{2}-1}-\frac{\operatorname{ArcSinh}\left(\sqrt{a^{2}-1}\right)}{\left(a^{2}-1\right)^{\frac{3}{2}}}\right)$, is strictly

decreasing in cost weight $a$ for $a<1$.

Proof

$$
\begin{aligned}
m[a]= & m^{Y}[a]+m^{X}[a] \\
= & \int_{0}^{1}\left(\left(x \circ b_{Y}\left[v_{Y}\right]\right) \cdot\left(b_{Y}\left[v_{Y}\right]\right)\right) d v_{Y}+\int_{0}^{1}\left(y \circ b_{X}\left[v_{X}\right]\right) \cdot b_{X}\left[v_{X}\right] d v_{X} \\
= & \int_{0}^{1}\left(\frac{v_{Y}}{\sqrt{v_{Y}^{2}+a^{2}\left(1-v_{Y}^{2}\right)}} \cdot \frac{\sqrt{a^{2}+v_{Y}^{2}-a^{2} v_{Y}^{2}}-a}{v_{Y}-a^{2} v_{Y}}\right) d v_{Y} \\
& +\int_{0}^{1}\left(\left(\frac{a v_{X}}{\sqrt{1-\left(1-a^{2}\right) v_{X}^{2}}}\right) \cdot \frac{1-\sqrt{1-v_{X}^{2}+a^{2} v_{X}^{2}}}{v_{X}-a^{2} v_{X}}\right) d v_{X} \\
= & \left(\frac{1}{\left(1-a^{2}\right)}-\frac{a \cdot \operatorname{ArcCsch}\left(\frac{a}{\sqrt{1-a^{2}}}\right)}{\left(1-a^{2}\right)^{\frac{3}{2}}}\right)+a\left(\frac{1}{a^{2}-1}-\frac{\operatorname{ArcSinh}\left(\sqrt{a^{2}-1}\right)}{\left(a^{2}-1\right)^{\frac{3}{2}}}\right) .
\end{aligned}
$$

This expression is strictly decreasing in $a ; \frac{d m[a]}{d a}>0$ has been determined numerically.

e. The profit of the holding company,

$$
\begin{aligned}
\pi_{\text {Holding Company }}^{Y}[a] & =\frac{\sqrt{1-a^{2}}-(2-a) a \operatorname{ArcCsch}\left(\frac{a}{\sqrt{1-a^{2}}}\right)}{2\left(1-a^{2}\right)^{\frac{3}{2}}}-w^{0} \\
& +\gamma\left(\frac{1}{\left(1-a^{2}\right)}-\frac{a \cdot \operatorname{ArcCsch}\left(\frac{a}{\sqrt{1-a^{2}}}\right)}{\left(1-a^{2}\right)^{\frac{3}{2}}}-a\left(\frac{\operatorname{ArcSinh}\left(\sqrt{a^{2}-1}\right)}{\left(a^{2}-1\right)^{\frac{3}{2}}}+\frac{1}{1-a^{2}}\right)\right)
\end{aligned}
$$

, reaches an optimum for $a^{\mathrm{I} *} \approx 0.319404$. The profit is then 
$\pi^{\text {COMPOUND }}\left[a^{\mathrm{I} *}\right] \approx 0.560315-w^{0}$.

Proof:

$$
\begin{aligned}
\pi_{\text {Holding Company }}^{Y}[a]= & m[a]+\pi_{\text {Generator }}^{Y}[a] \\
= & \left(\frac{1}{\left(1-a^{2}\right)}-\frac{a \cdot \operatorname{ArcCsch}\left(\frac{a}{\sqrt{1-a^{2}}}\right)}{\left(1-a^{2}\right)^{\frac{3}{2}}}\right)+a\left(\frac{1}{a^{2}-1}-\frac{\operatorname{ArcSinh}\left(\sqrt{a^{2}-1}\right)}{\left(a^{2}-1\right)^{\frac{3}{2}}}\right) \\
& +\frac{(2-a) \operatorname{ArcCsch}\left(\frac{a}{\sqrt{1-a^{2}}}\right)-\sqrt{1-a^{2}}}{2\left(1-a^{2}\right)^{\frac{3}{2}}}-w^{0} .
\end{aligned}
$$

The optimal cost weight, $a^{\mathrm{I} *} \approx 0.319404$, has been approximated numerically.

f. The profit of independent bidder X,

$$
\pi_{\text {Generator }}^{X}[a]=\frac{a\left((a-2) \sqrt{-1+a^{2}}+\operatorname{ArcSinh}\left(\sqrt{a^{2}-1}\right)\right)}{2\left(-1+a^{2}\right)^{\frac{3}{2}}}, \text { is strictly increasing in cost }
$$

weight $a$ for $a<1$.

Proof:

The profit of independent bidder $\mathrm{X}$ is

$$
\begin{gathered}
\pi_{\text {Generator }}^{X}[a]=\int_{0}^{1} y \circ b_{X}\left[v_{X} ; a\right] \cdot\left(v_{X}-b_{X}\left[v_{X} ; a\right]\right) d v_{X} \\
=\int_{0}^{1} \frac{v_{Y}}{\sqrt{v_{Y}^{2}+a^{2}\left(1-v_{Y}^{2}\right)}} \cdot\left(v_{Y}-\frac{\sqrt{a^{2}+v_{Y}{ }^{2}-a^{2} v_{Y}^{2}}-a}{v_{Y}-a^{2} v_{Y}}\right) d v_{X} \\
=\frac{a\left((a-2) \sqrt{-1+a^{2}}+\operatorname{ArcSinh}\left(\sqrt{a^{2}-1}\right)\right)}{2\left(-1+a^{2}\right)^{\frac{3}{2}}} .
\end{gathered}
$$

$\frac{d \pi_{\text {Generator }}^{X}[a]}{d a}>0$ has been determined numerically.

g. The strategic profit of the holding company is equal to the profit of the holding 
company, $\pi_{\text {Holding Company }}^{Y}[a]$, minus the passive profit $\pi_{\text {Holding Company }}^{Y}[a=1]=\frac{1}{6}+\frac{\gamma}{3}$,

and therefore reaches its maximum of $\pi_{\text {Strategic }}^{Y}\left[a^{\mathrm{I}} *\right] \approx 0.060$ at $a^{\mathrm{I}} * \approx 0.319404$ just as $\pi_{\text {Holding Company }}^{Y}[a]$

h. The welfare, $W[a]=\frac{1}{2}\left(1-\frac{a^{2} \operatorname{ArcCsch}\left(\frac{a}{\sqrt{1-a^{2}}}\right)}{\left(1-a^{2}\right)^{\frac{3}{2}}}-\frac{a \operatorname{ArcSinh}\left(\sqrt{a^{2}-1}\right)}{\left(a^{2}-1\right)^{\frac{3}{2}}}\right)$, is strictly increasing in cost weight $a$ for $a<1$.

Proof:

$$
\begin{aligned}
W[a]= & \pi_{\text {Generator }}^{X}[a]+\pi_{\text {Generator }}^{Y}+m[a]+w^{0} \\
= & \left.\frac{a\left((a-2) \sqrt{-1+a^{2}}+\operatorname{ArcSinh}\left(\sqrt{a^{2}-1}\right)\right)}{2\left(-1+a^{2}\right)^{\frac{3}{2}}}-w^{0}+\frac{(2-a) \operatorname{ArcCsch}\left(\frac{a}{\sqrt{1-a^{2}}}\right)-\sqrt{1}}{2\left(1-a^{2}\right)^{\frac{3}{2}}}\right)+a\left(\frac{1}{a^{2}-1}-\frac{\operatorname{ArcSinh}\left(\sqrt{a^{2}-1}\right)}{\left(1-a^{2}\right)^{\frac{3}{2}}}\right)+w^{0} \\
& +\left(\frac{1}{\left(1-a^{2}\right)}-\frac{\left.a \cdot a^{2}-1\right)^{\frac{3}{2}}}{\sqrt{1-a^{2}}}\right) \\
= & \frac{1}{2}\left(1-\frac{a^{2} \operatorname{ArcCsch}\left(\frac{a}{\sqrt{1-a^{2}}}\right)}{\left(1-a^{2}\right)^{\frac{3}{2}}}-\frac{a \operatorname{ArcSinh}\left(\sqrt{a^{2}-1}\right)}{\left(a^{2}-1\right)^{\frac{3}{2}}}\right) .
\end{aligned}
$$

This expression is decreasing in cost weight $a$. $\frac{d W[a]}{d a}>0$ has been determined numerically.

\section{Proposition 4}

When independent bidder $\mathrm{X}$ believes allied bidder $\mathrm{Y}$ to maximize profits then the 
outcomes in a first-price auction are identical to those in a second-price auction.

Proof:

Independent bidder $\mathrm{X}$ believing allied bidder $\mathrm{Y}$ to maximize profits is equal to $\mathrm{X}$ believing the allied bidder maximizes a compensation scheme with a cost weight set equal to one. $\mathrm{X}$ then bids, as in the symmetrical model,

$b_{X}=\frac{v_{X}}{2}$ and $x[b]=2 b$.

Let us assume that $\mathrm{Y}$ is aware of the ignorance (or skepticism) of $\mathrm{X}$. This makes it possible for Y to logically deduce that $x[b]=2 b$. Substituting for $x[b]$ into equation 4 gives:

$v_{Y}-a b_{Y}=\frac{a \cdot x\left[b_{Y}\right]}{x^{\prime}\left[b_{Y}\right]}=\frac{a \cdot 2 b_{Y}}{2}=a b_{Y}$

$b_{Y}=\frac{v_{Y}}{2 a}$, implying $y[b]=2 a b$.

With the above bidding functions, it follows that:

a) The auction revenue is equal to $m[a]=\frac{3-a}{6}$

b) The profit of allied bidder $\mathrm{Y}$ is given by $\pi_{\text {Generator }}^{Y}[a]=\frac{a(2-a)}{6}-w^{0}$

c) The profit of allied bidder $\mathrm{X}$ is given by $\pi_{\text {Generator }}^{X}[a]=\frac{a}{6}$.

The above outcomes are identical with the outcomes of second-price auctions. As the profit of the holding company and welfare is computed from the three outcomes above, these are also identical. As a result, revenue equivalence has been restored. Moreover, the effect of ownership share $\gamma$ on the holding company's choice of cost weight will be the same; hence the same cost weight will be maximizing.

a) Proof of $m[a]=\frac{3-a}{6}$. 


$$
\begin{aligned}
m[a]= & m^{X}[a]+\left(m^{Y}[a]\right) \\
& =\int_{0}^{1} a v_{X}\left(b_{X}\right) d v_{X}+\left(\int_{0}^{a} \frac{v_{Y}}{a}\left(b_{Y}\right) d v_{Y}+\int_{a}^{1} \frac{1}{2} d v_{Y}\right) \\
& =\int_{0}^{1} \frac{a v_{X}^{2}}{2} d v_{X}+\left(\int_{0}^{a} \frac{v_{Y}^{2}}{2 a^{2}} d v_{Y}+\int_{a}^{1} \frac{1}{2} d v_{Y}\right) \\
& =\left[\frac{a v_{X}^{3}}{6}\right]_{0}^{1}+\left(\left[\frac{v_{Y}^{3}}{6 a^{2}}\right]_{0}^{a}+\left[\frac{v_{Y}}{2}\right]_{a}^{1}\right) \\
& =\frac{a}{6}+\left(\frac{a}{6}+\frac{1-a}{2}\right) \\
& =\frac{3-a}{6} .
\end{aligned}
$$

b) Proof of $\pi_{\text {Generator }}^{Y}[a]=\frac{a(2-a)}{6}-w^{0}$ :

$$
\begin{aligned}
\left.\pi_{\text {Generator }[a]}^{Y}\right] & =\int_{0}^{a} \frac{v_{Y}}{a}\left(v_{Y}-b_{Y}\right) d v_{Y}+\int_{a}^{1}\left(v_{Y}-\frac{1}{2}\right) d v_{Y}-w^{0} \\
& =\int_{0}^{a} \frac{v_{Y}}{a}\left(v_{Y}-\frac{v_{Y}}{2 a}\right) d v_{Y}+\int_{a}^{1}\left(v_{Y}-\frac{1}{2}\right) d v_{Y}-w^{0} \\
& =\int_{0}^{a} \frac{v_{Y}^{2}}{a}\left(\frac{2 a-1}{2 a}\right) d v_{Y}+\int_{a}^{1}\left(v_{Y}-\frac{1}{2}\right) d v_{Y}-w^{0} \\
& =\left[\frac{v_{Y}^{3}}{3 a} \cdot \frac{2 a-1}{2 a}\right]_{0}^{a}+\left[\frac{v_{Y}^{2}-v_{Y}}{2}\right]_{a}^{1}-w^{0} \\
& =\frac{a(2 a-1)}{6}+\frac{a-a^{2}}{2}-w^{0} \\
& =\frac{a(2 a-1)}{6}+\frac{3 a-3 a^{2}}{6}-w^{0} \\
& =\frac{a(2-a)}{6}-w^{0} .
\end{aligned}
$$

c) Proof of $\pi_{\text {Generator }}^{X}[a]=\frac{a}{6}$; 


$$
\begin{aligned}
\pi_{\text {Generator }}^{X}[a] & =\int_{0}^{1} a v_{X}\left(v_{X}-b_{X}\right) d v_{X} \\
& =\int_{0}^{1} a v_{X}\left(v_{X}-\frac{v_{X}}{2}\right) d v_{X} \\
& =\int_{0}^{1} \frac{a v_{X}^{2}}{2} d v_{X} \\
& =\left[\frac{a v_{X}^{3}}{6}\right]_{0}^{1} \\
& =\frac{a}{6} .
\end{aligned}
$$




\section{References}

Averch, H., Johnson, L.L., 1962. Behavior of the firm under regulatory constraint. The American Economic Review 63(2), 90-97.

Baumol, W., 1958. On the theory of oligopoly. Economica (Aug.) 25, 187-98.

Brunekreeft, G., Neuhoff, K., Newbery, D., M., 2006. Electricity transmission: an overview of the current debate. Cambridge Working Papers in Economics. Available at https://www.dspace.cam.ac.uk/handle/1810/277.

Commission of the European Communities, 2004. Third benchmarking report on the implementation of the internal electricity and gas market. DG Tren draft working paper. Available at http://europa.eu.int/comm/energy/electricity.

Commission of the European Communities, 2005. Technical annexes to the report on progress in creating the internal gas and electricity market. DG Tren draft working paper. Available at http://europa.eu.int/comm/energy/electricity

CONSENTEC, 2004. Analysis of cross-border congestion management methods for the EU internal electricity market. Available at http://europa.eu.int/comm/energy/electricity/publications/.

Dewatripont, M., 1988. Commitment through renegotiation-proof contracts with third parties. Review of Economic Studies 55, 377-289.

Electrabel webside. Available at www.electrabel.com.

European Commission Competition DG, 10 January 2007, DG competition report on energy sector inquiry. Available at http://ec.europa.eu/comm/competition/sectors/energy/inquiry/.

European Transmission System Operators (ETSO), 2004. Overview congestion management methods. Available at http://www.etsonet.org/upload/documents/Current_CM_methods_final_20040908.pdf.

Fershtman, C., Judd, K.L., 1987. Equilibrium incentives in oligopoly. The American Economic Review Vol. 77, No.5, 927-940.

Fudenberg, D., Tirole, J., 1984. The fat-cat effect, the puppy-dog ploy, and the lean and hungry look. American Economic Review vol. 74(2), 361-66.

Katz, M., L., 1991. Game-playing agents: Unobservable contracts as precommitments. RAND Journal of Economics, The RAND Corporation vol. 22(3), 307-328. 
Krishna, V., 2002. Auction theory. San Diego, Cal.: Academic Press.

Léautier, T., 2001. Transmission constraints and imperfect markets for power. Journal or regulatory economics 19 (1), 27-54.

London Economics, 2004. Structure and functioning of the electricity market in Belgium in a European perspective. Available at http://www.creg.be/pdf/Etudes/ARCG-LE102004.pdf.

Parisio, L., Bosco, B., 2003. Market power and the power market: multi-unit bidding and (in)efficiency in electricity auctions. International Tax and Public Finance $10,377-401$.

Sklivas, S., 1987. The strategic choice of managerial incentives. RAND Journal of Economics Vol. 18 (3), 452-458.

Van Koten, S., 2006. Bidding behavior when one bidder and the auctioneer are vertically integrated. Implications for the partial deregulation of EU electricity markets. CERGE-EI Working Paper 313. Center for Economic Research and Graduate Education - Economic Institute, Prague. Available at http://www.cerge-ei.cz/pdf/wp/Wp313.pdf.

Van Koten, S., Ortmann, A., 2006. The unbundling regime for electricity utilities in the EU: A case of legislative and regulatory capture? CERGE-EI Working Paper 328. Center for Economic Research and Graduate Education - Economic Institute, Prague. Available at http://www.cerge-ei.cz/pdf/wp/Wp328.pdf.

\section{Notation overview}

$a$

$a \in[0,1]$ is the cost weight the holding company sets on the bidding costs of allied bidder $\mathrm{Y}$ when computing the bonus of manager $\mathrm{Y}^{\mathrm{m}}$. When manager $\mathrm{Y}^{\mathrm{m}}$ wins the auction with bid $b$, his bonus increases on the margin with the value of transmission minus $a$ times the bid.

$b$ $b \in[0, \bar{b}] \subseteq[0,1]$ is the officially stated bid offered by a bidder. $\bar{b} \in[0,1]$ is the highest bid in the auction. 
$b_{Y}[v] \quad$ The optimal bid of allied bidder $Y$ given his realized value $v \in[0,1]$. This strategy $b_{Y}[\cdot]$ has the inverse $y[\cdot]$ (such that $y\left[b_{Y}[v]\right]=v$ ).

$b_{X}[v] \quad b_{X}[v]$ is the optimal bid of independent generator $\mathrm{X}$ given her realized value $v \in[0,1]$. This strategy $b_{X}[v]$ has the inverse $x[\cdot]$ (such that $\left.x\left[b_{X}[v]\right]=v\right)$.

$\gamma \quad \gamma \in[0,1]$ is the ownership share that the holding company holds in the auctioneer. The holding company therefore receives portion $\gamma$ of the revenue of the auctioneer.

$p^{Y W I N S}[a] \quad$ The ex-ante expected probability that allied bidder $\mathrm{Y}$ wins when using (his optimal) strategy $b_{Y}[\cdot]$, given cost weight $a$.

$\pi_{\text {Generator }}^{Y}[a] \quad$ The ex-ante expected private profit of allied bidder Y.

$\pi_{\text {Holding Company }}^{Y}[a, \gamma]$ The expected profit of the holding company when it sets the cost weight equal to $a$ when the holding company has an ownership share of $\gamma$. When setting the optimal cost weight, the expected profit of the holding company is equal to $\pi_{\text {Holding Company }}^{Y}[\gamma]=\pi_{\text {Holding Company }}^{Y}[a[\gamma], \gamma]$. $\bar{\pi}_{\text {Passive }}^{Y}[\gamma] \quad \bar{\pi}_{\text {Passive }}^{Y}[\gamma]=\pi_{\text {Holding Company }}^{Y}[a=1, \gamma]+\gamma m[a=1]$ is the ex-ante expected passive profit of the holding company. It is the profit when the holding company has an ownership share of $\gamma$, but sets the cost weight in the compensation scheme equal to one.

$\pi_{\text {Strategic }}^{Y}[\gamma] \quad \pi_{\text {Strategic }}^{Y}[\gamma]=\pi_{\text {Holding Company }}^{Y}[\gamma]-\bar{\pi}_{\text {Passive }}^{Y}[\gamma]$ is the ex-ante expected strategic profit. It is the extra profit that can be made by giving manager $\mathrm{Y}^{\mathrm{m}}$ a compensation scheme.

$m^{Y}[\gamma] \quad$ The ex-ante expected payment of allied bidder $\mathrm{Y}$ when the allied bidder has a realized value of $v_{Y}$ and the ownership share is $\gamma$.

$m[\gamma] \quad m[\gamma]=m^{Y}[\gamma]+m^{X}[\gamma]$ is the ex-ante expected revenue of the auctioneer, when the ownership share is $\gamma$. 
$v \in[0,1]$ is the value of transmission in the auction. It is a random variable uniformly distributed on $[0,1]$.

$W[\gamma] \quad$ The ex-ante expected welfare. It is the value of transmission in use by the bidder that won the auction.

$x[\cdot] \quad$ The inverse of strategy $b_{X}[v]$ (such that $\left.x\left[b_{X}[v]\right]=v\right)$.

$y[\cdot] \quad$ The inverse of strategy $b_{Y}[\cdot]$ (such that $y\left[b_{Y}[v]\right]=v$ ). 
Individual researchers, as well as the on-line and printed versions of the CERGE-EI Working Papers (including their dissemination) were supported from the following institutional grants:

- Center of Advanced Political Economy Research [Centrum pro pokročilá politickoekonomická studia], No. LC542, (2005-2009),

- Economic Aspects of EU and EMU Entry [Ekonomické aspekty vstupu do Evropské unie a Evropské měnové unie], No. AVOZ70850503, (2005-2010);

- Economic Impact of European Integration on the Czech Republic [Ekonomické dopady evropské integrace na ČR], No. MSM0021620846, (2005-2011);

Specific research support and/or other grants the researchers/publications benefited from are acknowledged at the beginning of the Paper.

(c) Silvester van Koten, 2007

All rights reserved. No part of this publication may be reproduced, stored in a retrieval system or transmitted in any form or by any means, electronic, mechanical or photocopying, recording, or otherwise without the prior permission of the publisher.

Published by

Charles University in Prague, Center for Economic Research and Graduate Education (CERGE) and

Economics Institute ASCR, v. v. i. (EI)

CERGE-El, Politických vězňů 7, 11121 Prague 1, tel.: +420 224005 153, Czech Republic.

Printed by CERGE-EI, Prague

Subscription: CERGE-EI homepage: http://www.cerge-ei.cz

Editors: Directors of CERGE and EI

Managing editors: Deputy Directors for Research of CERGE and EI

ISSN 1211-3298

ISBN 978-80-7343-145-7 (Univerzita Karlova. Centrum pro ekonomický výzkum

a doktorské studium)

ISBN 978-80-7344-134-0 (Národohospodářský ústav AV ČR, v. v. i.) 
CERGE-EI

P.O.BOX 882

Politických vězňů 7

11121 Praha 1

Czech Republic http://www.cerge-ei.cz 